\title{
Allelopathy of Aquatic Autotrophs
}

\author{
Elisabeth M. Gross \\ Limnological Institute, University of Konstanz, 78457 Konstanz, Germany \\ Elisabeth.Gross@uni-konstanz.de
}

Referee: Dr. Friedrich Jüttner, Universität Zürich-Limnologische Station, Institut für Pfilanzen biologie, Universität Zürich, Seestrasse 187, Ch-8802 Klichberg ZH, Switzerland

\begin{abstract}
Allelopathy in aquatic environments may provide a competitive advantage to angiosperms, algae, or cyanobacteria in their interaction with other primary producers. Allelopathy can influence the competition between different photoautotrophs for resources and change the succession of species, for example, in phytoplankton communities. Field evidence and laboratory studies indicate that allelopathy occurs in all aquatic habitats (marine and freshwater), and that all primary producing organisms (cyanobacteria, micro- and macroalgae as well as angiosperms) are capable of producing and releasing allelopathically active compounds. Although allelopathy also includes positive (stimulating) interactions, the majority of studies describe the inhibitory activity of allelopathically active compounds. Different mechanisms operate depending on whether allelopathy takes place in the open water (pelagic zone) or is substrate associated (benthic habitats). Allelopathical interactions are especially common in fully aquatic species, such as submersed macrophytes or benthic algae and cyanobacteria. The prevention of shading by epiphytic and planktonic primary producers and the competition for space may be the ultimate cause for allelopathical interactions. Aquatic allelochemicals often target multiple physiological processes. The inhibition of photosynthesis of competing primary producers seems to be a frequent mode of action. Multiple biotic and abiotic factors determine the strength of allelopathic interactions. Bacteria associated with the donor or target organism can metabolize excreted allelochemicals. Frequently, the impact of surplus or limiting nutrients has been shown to affect the overall production of allelochemicals and their effect on target species. Similarities and differences of allelopathic interactions in marine and freshwater habitats as well as between the different types of producing organisms are discussed.
\end{abstract}

KEY WORDS: marine ecosystem, freshwater ecosystem, algae, cyanobacteria, angiosperms, coral, ecology.

\section{INTRODUCTION}

Aquatic photoautotrophs often face severe competition for resources, either space, light, or nutrients. The release of allelopathically active compounds interfering with settlement and/or growth of competitors in their vicinity is an adaptive trait developed by primary producers against competitors. According to Molisch (1937), allelopathy covers biochemical interactions, both stimulatory and inhibitory, among different primary producers or between primary producers and microorganisms. Similar to terrestrial habitats, final proof for allelopathic interactions in aquatic systems is almost impossible. Most aquatic studies cover only a few of the six requirements demanded by Willis (1985), often neglecting eco- logical aspects of allelopathy. Even so, many studies point toward allelopathic interactions among aquatic photoautotrophs, sometimes substantiated by both field and laboratory evidence.

This review has the following objectives: (1) to summarize current knowledge of allelopathic interactions in all aquatic systems, (2) to name factors and constraints for allelopathy in these environments, and (3) to emphasize common patterns in both freshwater and marine habitats. The main attention was given to studies published within the last decade, and reference was made to general reviews of this topic (Gopal and Goel, 1993; Inderjit and Dakshini, 1994; Gross, 1999). First, the article covers current knowledge on allelopathically active primary producers in marine and freshwater habitats. Within these habitats, different groups of 
primary producers involved (angiosperms, macroand microalgae, cyanobacteria) have been distinguished. Cyanobacteria were separated from other microalgae because they are prokaryotes and are generally known to produce a vast array of novel secondary metabolites. Secondly, general aspects of allelopathy, such as the mode of action of allelopathically active compounds and environmental and biotic factors acting on the production of allelochemicals, are discussed. This part bridges insights from different habitats and producing organisms. Apparently there are general principles to all aquatic habitats and most primary producers.

\section{A. Differences between Terrestrial and Aquatic Habitats}

Generally, allelopathic interactions in aquatic habitats resemble those in terrestrial systems, although some fundamental differences exist. One major difference is that most aquatic photoautotrophs are surrounded by water instead of air. Allelochemicals released by donor organisms into the water need to be sufficiently hydrophilic and reach their target organisms in effective concentrations despite considerable dilution. We might expect less lipophilic allelochemicals in this habitat compared with terrestrial sites where transfer through the air is possible. Further, algae, cyanobacteria, and fully aquatic angiosperms are 'leaky', maybe even more than terrestrial plants. Submersed leaves of aquatic angiosperms have no stomata, a reduced cuticula, and less tight cell connections compared with emergent or floating leaves (Hutchinson, 1975), all of which should facilitate the release of organic compounds. Leaves of terrestrial plants are generally protected by a thick cuticula. However, leakage through open stomata or from epidermal cells may occur. To my knowledge, a direct comparison between aquatic and terrestrial photoautotrophs for qualitative and/or quantitative differences in organic leachates was never done. Both algae (Sieburth, 1968; Wood et al., 1992), and higher plants (Wetzel, 1969; Wetzel and Manny, 1972; Søndergaard, 1981; Nalewajko and Godmaire, 1993) release organic compounds, usually referred to as DOC (dissolved organic carbon/compounds) or EOC (extracellular organic carbon/compounds). Leachates contain mainly carbon-based organic compounds, considered to be surplus photosynthates (Wetzel, 1969; Hough and Filbin, 1990). Besides pure carbon-based compounds, dissolved organic nitrogen compounds are also found (Wetzel and Manny, 1972).

Allelopathic interactions of aquatic photoautotrophs may also occur via root exudation. Commonly, simplified model systems are used to evaluate allelopathic root exudates (Gallardo et al., 1998b; Kato-Noguchi and Ino, 2001). Yet, physico-chemical processes in root compartments (of terrestrial plants) are diverse and may be complex. Their effect on various interactions, among them allelopathy, was discussed recently by ElShatnawi and Makhadmeh (2001). The importance of soil processes in terrestrial systems for allelopathic interactions involving phenolic compounds were analyzed in detail by Blum et al. (1999). A major difference in aquatic habitats compared with terrestrial systems is that the sediment is waterlogged, creating anaerobic environments. Most aquatic macrophytes manage to create small oxygenic boundary layers around their roots (Christensen et al., 1994; Flessa, 1994; Sorrell and Armstrong, 1994; Brix and Sorrell, 1996; Wigand et al., 1997; Jackson and Armstrong, 1999). Aerobic microzones around roots of aquatic angiosperms are small (approx. $1 \mathrm{~mm}$ ), but may significantly alter the redox potential of the soil (Flessa, 1994). Certainly, these microzones have an impact on the transfer of allelopathically active compounds, although few direct studies have been performed so far. The relevance of aquatic bioactive metabolites in the rhizosphere and around roots was discussed recently by Neori et al. (2000).

Two different types of allelopathic interactions occur in aquatic habitats. First, pelagic algae and cyanobacteria may use allelopathically active compounds to outcompete other species, to gain dominance over predecessors, or influence the type of conspecifics and successors. Fundamental studies have been done by Keating $(1977,1978)$ on allelopathy and the cyanobacterial dominance in eutrophic lakes. Allelopathy in pelagic environments depends on sufficient production and excretion of allelopathically active compounds 
into the water and their effective distribution to reach target species at active concentrations. Dilution is the major problem in this type of allelopathic interaction (Lewis, 1986). We may consider the pelagic zone as a three-dimensional habitat compared with littoral or benthic zones, where the competition for space is more severe and the colonized surface represents rather a twodimensional habitat. Thus, secondly, in aquatic environments we are dealing with allelopathic interactions between organisms living adjacent to each other, sometimes even touching other species in littoral or benthic zones. In these habitats angiosperms and macroalgae, so-called 'macrophytes' (see Wetzel, 2001), compete with other macrophytes, epiphytes, and/or phytoplankton. Allelopathically active compounds produced by benthic photoautotrophs that affect phytoplankton rely on similar mechanisms than described for the pelagic habitat. When macrophytes excrete allelochemicals targeting epiphytes, these compounds may be passed along either via the water or by direct contact, that is, compounds located in secretory trichomes, epidermal glands, or otherwise associated with the surface of the plant. In this case we can assume high local concentrations of allelochemicals directly acting on target species. We may consider more hydrophilic compounds acting on plankton species, whereas compounds translocated by direct contact should be more lipophilic. Leaf washings, as used with terrestrial plants to remove lipophilic substances from the surface, are difficult with aquatic angiosperms. Surface concentrations of natural products on marine macroalgae have been quantified using short hexane washings (de Nys et al., 1998; Dworjanyn et al., 1999).

The presence of surface-associated allelochemicals does not exclude allelochemicals with low water solubility in pelagic allelochemical interactions, since lipophilic compounds may bind to small particles or form micelles (Fischer and Quijano, 1985; Perez, 1999; Perez and Martin, 2001). Micelle formation as a means of increasing the solubility of lipophilic allelochemicals in water, however, has been debated, and other mechanisms may also be involved (Fischer et al., 1994).

Some studies report allelopathic interactions between terrestrial and aquatic photoautotrophs.
In the last decade, many studies have investigated the algicidal effect of (deciduous) leaf litter and (barley) straw (i.e., Dasneves and Gaspar, 1990; Newman and Barrett, 1993; Pillinger et al., 1994; Lege et al., 1995; Martin and Ridge, 1999; Ridge et al., 1999; Al Hamdi et al., 2001). Especially in small lakes and rivers, leaf litter may strongly influence algal communities. The use of straw to prevent cyanobacterial blooms represents, however, an artificial coupling of terrestrial and aquatic organisms. Wetland plants are at the interface of terrestrial and aquatic systems. Some of them have allelopathic properties (Elakovich and Wooten, 1989; Rojo et al., 2000). Rice, an important wetland crop, was affected by allelopathic interference from cyanobacteria (Inderjit and Dakshini, 1997) or aquatic plants (Quayyum et al., 1999a, 1999b).

\section{B. Suitable Target Organisms and Impact of Stressors on Allelopathy}

The debate on the existence of allelopathy in situ and how to transfer laboratory results to field situations is ongoing for both terrestrial and aquatic systems and will not be settled on in the near future, as already mentioned. Much controversy arises from the use of adequate bioassays, above normal concentrations of inhibitors, or wrong target organisms. Reviews on laboratory bioassays are available by Inderjit and Dakshini (1995) and Inderjit (this issue). Some of the constrains of allelopathy occurring in situ have been discussed recently by Reigosa et al. (1999).

Allelopathic interactions apparently are enhanced under abiotic or biotic stress (Lovett et al., 1989; Tang et al., 1995; Reigosa et al., 1999). This is corroborated by many studies showing the impact of nutrient limitation of both donor and target organisms on the outcome of allelopathic interactions (see Section VI.A). Complex field situations may have one or multiple stressors acting at the same time, a facet not yet much reflected in aquatic allelopathy research. Further, temporal and spatial changes in stressors acting on competing primary producers occur. Inorganic phosphorus is the major limiting nutrient for algae and cyanobacteria in summertime (Schindler, 
1977). Ultraviolet radiation is strongest in summer; the depth reached in aquatic systems strongly depends on the clarity of the water (Haeder et al., 1998). Generally, UV-stress seems less important for most freshwater systems (Williamson, 1995) but has strong impacts on many marine habitats (Suzuki et al., 1998; Farjalla et al., 2001). Water stress (i.e., drought) is seldom a stressor in aquatic systems. It is not unlikely that the presence or absence of allelopathic interactions in a given system is related to changes in stressors acting on the organisms. There is some potential that studies incorporating common stressors may resolve contradicting results on allelopathic activity.

The question of whether target species have to be from the same habitat than the donor organism is also discussed as controversial. It seems obvious that aquatic allelochemicals should not be tested on terrestrial plants since there is no ecological relevance. The argument that proper ecological studies should use donor and target species from the same habitat refers mainly to the use of artificial systems for allelopathic studies. In spite of that, terrestrial plants or plant parts are sometimes used additionally to aquatic target organisms because they may provide the better model systems for a detailed investigation of the mode of action (e.g., spinach chloroplasts for photosynthesis inhibition [see Section IV.B.]). The use of cultured algae or cyanobacteria in aquatic allelopathy is frequent because they allow bioassays to be run under controlled and replicated conditions. Reigosa et al. (1999) argued that organisms within one habitat should be adapted to allelochemicals in this system. Therefore, allelopathic interactions should only be expected between organisms from different habitats. Allelopathic interactions among aquatic photoautotrophs would consequently be more likely if the organisms originate from different lakes or streams, maybe even from different geographical regions. Unfortunately, we are lacking studies directly addressing this aspect. It would be interesting to see if Reigosa's hypothesis (Reigosa et al., 1999) is also generally applicable for aquatic ecosystems. More insight could arise from a comparison of the allelopathical potential of aquatic neophytes and their native relatives. Nevertheless, allelopathy may act between organisms of one habitat or between those from different sites. Considering that some allelochemicals are inducible and their production controlled by stress or other environmental factors (see Sections I.A and V.A), we should expect a changing susceptibility of target organisms to allelopathically active species within one habitat. Further, the studies by Keating (1977, 1978) showed that allelopathy might explain phytoplankton succession within one lake. Thus, not only spatial concerns (same or different original habitat of interfering species) but also temporal aspects (climax of stressors, seasonal succession of species) need reference.

\section{MARINE SYSTEMS}

Allelopathy in marine ecosystems may occur between phytoplankton species or in benthic areas where macroalgae, corals, and a few species of angiosperms are present. Benthic zones are small compared with the vast pelagic zones in the sea. Phytoplankton densities are extremely low in mid ocean, but may increase considerably along the shores as a result of eutrophication. Angiosperms, macroalgae, and corals produce inhibitory compounds interfering with epiphytes and other epibionts, competing for light and/or space (Harrison and Chan, 1980; Harlin, 1987; Endean et al., 1997; Jeong et al., 2000). Allelochemical interactions among planktonic algae have been described, mainly when bloom-forming microalgae were involved (Smayda, 1997).

\section{A. Angiosperms}

Only few aquatic angiosperms live in marine littoral areas. Their distribution depends on sediment characteristics (sandy, not rocky shore) and turbidity caused by biotic or abiotic factors (see, e.g., Orth et al., 2000). Zostera marina often dominates worldwide seagrass communities. Watersoluble extracts from both green and dead leaves of Z. marina inhibited algae and bacteria (Harrison and Chan, 1980; Harrison and Durance, 1985). Dead leaves were active only shortly after senescence. It is likely that phenolic allelochemicals were responsible for the observed effect 
(Quackenbush et al., 1986; Harrison and Durance, 1989). The highest concentrations of phenolic compounds ( $1.5 \%$ based on dry mass) were found in September, at the end of the active growing season (Harrison and Durance, 1989). One might expect algicidal compounds to be highest during maximum phytoplankton or epiphyte development, but in this case phenolic allelochemicals were not correlated to maximum densities of microalgae or cyanobacteria. Whether antimicrobial phenolic acid sulfate esters (Todd et al., 1993) also act on epiphytic algae or cyanobacteria has not yet been elucidated. Ruppia maritima (Potamogetonaceae) growing in brackish or salt water produces antialgal diterpenes (Della Greca et al., 2000a). To my knowledge, no other marine angiosperms produce allelopathically active compounds.

\section{B. Macroalgae}

Macroalgae in marine environments belong to various groups, predominantly to the phaeophytes, chlorophytes, and rhodophytes. Depending on their growth form (crustose or erect, sometimes canopy forming), they experience different interactions with other photoautotrophs, and also sometimes with heterotrophs. Allelochemical interference of macroalgae with microalgae has long been known (Shapiro, 1957; McLachlan and Craigie, 1964; Sieburth, 1968).

Prevention of epiphyte growth on macroalgal tissue by allelopathic mechanisms occurs frequently (Harlin, 1987). Extracts of various macroalgae inhibited the settlement and growth of the chlorophyte Enteromorpha prolifera (Young Cho et al., 2001), a common epiphyte on other macroalgae. Antifouling activity of macroalgae against bacteria and fungi was shown by Hellio et al. (2000). In their study, some macroalgae possessed antifungal activity, others antibacterial, and only Laurencia pinnatifida (Rhodomelaceae) exhibited both antifungal and antibacterial activity. Extracts from this rhodophyte also exhibited a strong antifouling activity against microalgae, comparable to that of heavy metals and biocides currently used in antifouling paints (Hellio et al., 2002). Several extracts from other macroalgae were also active. Allelopathy was apparently not involved in the prevention of epiphyte growth on the siphonaceous macroalgae Avrainvillea (Bryopsidales, Chlorophyta). The major cause for low epiphyte densities was identified as the reallocation of protoplasm for new growth through protoplasmic streaming, subsequent blade abandonment and proliferation (Littler and Littler, 1999). Exuded phlorotannins apparently were not allelopathically active since they did not affect the abundance and distribution of epiphytes on the phaeophyte Ecklonia radiata (Jennings and Steinberg, 1994; Jennings and Steinberg, 1997).

Crustose algae are prone to shading by canopyforming macroalgae. Allelopathy may be an effective defensive trait preventing severe light limitation. Crustose coralline algae of the genus Lithophyllum (Rhodophyceae) produced a lipophilic allelopathic substance of low molecular weight that destroyed zoospores of the phaeophyte Laminaria religiosa (Suzuki et al., 1998). Plocamium hamatum (Rhodophyceae) produces allelopathically active monoterpenes affecting both microalgae (König et al., 1999) and adjacently growing soft corals (de Nys et al., 1991). Certain marine macroalgae (Corallina pilulifera, Ulva pertusa, Ishige foliacea, and Endarachne binghamiae) exuded allelochemicals into the culture medium that inhibited toxic bloom-forming microalgae, such as Cochlodinium polykrikoides (Jeong et al., 2000). No seasonal variation was found for the algicidal activity, and extracts of $C$. pilulifera did not inhibit other, nontoxic microalgae.

\section{Microalgae}

Most of the 60 to 80 harmful marine phytoplankton species are flagellates, particularly dinoflagellates. To counteract low nutrient uptake affinities compared with diatoms, four major adaptations, among them allelopathy and grazing deterrence, have evolved in harmful flagellates (Smayda, 1997). Dominance of harmful dinoflagellate blooms in marine phytoplankton communities is considered to be mediated by the production of poisoning toxins, okadaic acid (OA), and dinophysistoxin-1 (DTX-1) (Lewis and 
Holmes, 1993; Windust et al., 1996; Plumley, 1997). Some studies suggested that OA and DTX-1 derived from Prorocentrum lima may have allelopathic properties and inhibit microalgae not forming toxins (Windust et al., 1996). However, a refined study showed that although OA had growth inhibitory activity, it was not the major allelopathically active compound present in $P$. lima. Three co-occurring dinoflagellates of $P$. lima exhibited reduced growth by another, yet unidentified allelochemical than OA (Sugg and van Dolah, 1999). Similar evidence that bloomforming microalgae may dominate phytoplankton, not only because they have feeding deterrents, but also because of allelopathic interactions with other phytoplankton species, has been reported recently. Culture filtrates of two raphidophytes (Heterosigma akashiwo and Chattonella antiquea) from the late logarithmic growth phase strongly inhibited the growth of the diatom Skeletonema costatum (Matsuyama et al., 2000). Three toxin-producing Alexandrium species exuded allelopathically active compounds inhibiting other microalgae (Chaetoceros gracile, Gymnodinium mikimotoi, and Scrippsiella trochoidea), both in the exponential and stationary growth phase (Arzul et al., 1999). Recent evidence indicates, however, that also bacteria might be involved in both induction and inhibition of cyst formation in the toxic $A$. tamarense (Adachi et al., 1999; Adachi et al., 2002), thus influencing the life cycle and bloom formation in this bloom-forming dinoflagellate.

\section{Cyanobacteria}

Despite the plethora of novel bioactive secondary metabolites isolated from marine cyanobacteria (e.g., Fish and Codd, 1994a; Moore, 1996; Abarzua et al., 1999; Nagle and Paul, 1999), almost nothing is known about allelopathic interactions. The production of grazer deterrents or antifouling metabolites (antifungal, antibacterial activity) is generally considered to determine competitive strength and allow toxin-producing strains to outcompete others. Many dominant species, for example, Lyngbya majuscula, produce a vast array of bioactive compounds (Nagle and Paul, 1999), but no allelopathically active com- pounds were isolated so far. Recently, it was shown that Nodularia harveyana, a nitrogen-fixing cyanobacterium isolated from the Mediterranean Sea, exhibited strong allelopathic activity against other axenic cyanobacteria, antibiotic activity against Gram-positive pathogenic bacteria, and antifungal activity against two plant pathogens (Pushparaj et al., 1998). Since many freshwater cyanobacteria (see below), especially benthic forms, produce allelopathically active compounds, we should expect similar activities in marine (benthic) cyanobacteria.

\section{E. Corals}

Corals were included in this review because anthozoa usually live in symbiosis with primary producers, zooxanthellae. The sessile nature of corals makes them vulnerable, being overgrown by macroalgae, especially under conditions of nutrient enrichment along reefs. In addition, competition for space with other corals exists. Therefore, it seems adaptive for corals to produce and release allelopathically active compounds deterring epibionts or adjacent organisms. Competition between scleractinian corals and benthic algae has been considered important for the structuring of coral reef communities (McCook et al., 2001). The regular spacing of massive coral blocks can be a result of allelopathic interference (Endean et al., 1997). The absence of higher plants at the Great Barrier Reef led to a screening for plant growth inhibitors. Specific inhibitors of $C_{4}$ plants were found in exudates of coral reef organisms by Jim Burnell and Lyndon Llewellyn (Thwaites, 2000). Nothing is yet known about the producing organisms, the chemical nature of the allelochemicals, and their ecological function.

Soft corals (e.g., Sinulariaflexibilis, Lobophytum hedleyi) inhibited growth and produced tissue necrosis in neighboring scleractinian corals due to the exudation of inhibitory terpenes (Aceret et al., 1995). The competition for space among some scleractinian corals seems to depend on allelopathy. Lipophilic extracts containing indole alkaloids isolated from Tubastrea faulkneri inhibited other scleractinians (Koh and Sweatman, 2000). Allelochemicals from alcyonacean octocorals (soft corals) have multiple 
functions; they may enhance reproductive success or act as antipredator, antifouling, and antialgal compounds (Sammarco, 1996; Griffith, 1997). Even antarctic soft corals produced allelopathically active compounds (as in the broader sense of allelopathy including animals) that prevented the growth of sponges on their surface (Slattery and McClintock, 1997).

Compounds active against fouling by epibionts may also interfere with other organisms colonizing neighboring space and therefore be adaptive for the coral. Corals are sometimes susceptible to allelochemicals released by neighboring sponges. The liver sponge Plakortis halichondroides caused necrosis of Agaricia lamarcki, a sheet coral (Porter and Targett, 1988). In addition, stimulating allelopathic effects have been observed. Allelochemicals released by alcyonacean corals enhanced the settlement and growth of scleractinian corals adapted to these compounds (Maida et al., 1995a,b).

However, often corals are target and not donor organisms, that is, they are susceptible to (inhibitory) allelochemicals released by co-occurring algae (McCook et al., 2001). Algae exerted allelopathic effects on both soft (de Nys et al., 1991) and hard corals (Littler and Littler, 1997).

\section{FRESHWATER SYSTEMS}

In freshwater systems we find allelopathic interactions among photoautotrophs both in pelagic zones and in benthic or littoral zones. In contrast to marine benthic areas, freshwater littoral zones are generally dominated by diverse aquatic angiosperms of different growth form, but only few macroalgae occur. Phytoplankton density may be high as a result of lake morphometry and trophic state (Wetzel, 2001). Different types of interaction among those primary producers occur, as illustrated below. Members of all groups of primary producers in freshwater have been shown to be involved in allelopathic interactions (Gopal and Goel, 1993; Inderjit and Dakshini, 1994; Gross, 1999). Apart from stagnant waters, primary producers grow also in running waters. In rivers and streams, the current would rapidly carry exuded allelochemicals away. With the ex- ception of benthic macroalgae (Dodds, 1991), no reports on allelopathy have been reported for this system.

\section{A. Angiosperms}

A comprehensive review of competition and allelopathy in aquatic plant communities was presented by Gopal and Goel (1993). Further references on allelopathy or secondary metabolites in aquatic angiosperms can be found in McClure (1970), Ostrofsky and Zettler (1986), WiumAndersen (1987), and Gross (1999). Therefore, I do not extensively cover all literature given there, but rather focus on more recent publications and selected macrophytes. Aquatic angiosperms are presented in three sections - emergent, floatingleaved, and submerged macrophytes - because of differences in habitat characteristics and growth form. Emergent plants seldom face competition with epiphytes or phytoplankton. However, these largely clonally dispersing species may compete with other emergents for nutrients and space. Floating leaved macrophytes cause shading for submerged growing macrophytes and phytoplankton. Rooted floating-leaved plants also compete for space because they predominantly spread vegetatively. True aquatic angiosperms living fully submerged face the strongest light and space competition with other primary producers, both higher plants and microalgae. Allelopathic interaction should be an efficient counteractive strategy for many of them. Sudden switches between phytoplankton or macrophyte dominance in many shallow eutrophic lakes occur frequently (Scheffer et al., 1993; Jeppesen et al., 1998). These changes are influenced by many abiotic and biotic factors, among them allelopathic interference of macrophytes with phytoplankton development (Crawford, 1977; Phillips et al., 1978; Gross, 1999; Scheffer, 1999).

\section{Emergent Macrophytes}

Allelopathic interactions in helophytes were reviewed by Szczepanska (1987). She focussed on interspecific effects of emergent macrophytes, 
such as Phragmites australis and Typha latifolia, both growing frequently in the same littoral area. Much is known about common reed species, such as Typha or Juncus, and only few studies deal with other emergent macrophytes. Acorus gramineus (Araceae) contains several phenylpropanoids with antialgal and anticyanobacterial activity (Della Greca et al., 1989).

Juncus effusus, a cosmopolitan clonal angiosperm, is highly competitive and possesses allelopathic activity. The algicidal activity was related to dihydrophenanthrene and tetrahydropyrene aglykones (Della Greca et al., 1996) and stereochemical requirements for inhibition were elucidated by synthesis of these and related compounds (Della Greca et al., 2000b, 2001b). Similar compounds are found in J. acutus (Della Greca et al., 2002a, 2002b), suggesting that this class of compounds is widespread in this genus. Additionally, antialgal phenylpropane glycerides were isolated from J. effusus (Della Greca et al., 1998). Leachates of dead, aboveground tissue of adult plants are autotoxic to seedlings (Ervin and Wetzel, 2000 ). Whether autotoxicity is based on the abovementioned algicidal compounds or other secondary metabolites present in this species (Corsaro et al., 1994; Della Greca et al., 1992a, 1993a, 1993b, $1994,1995,1996)$ remains to be elucidated. Autotoxicity toward seedlings in this otherwise vegetatively spreading plant may benefit temporal dispersal of seedling establishment and population regeneration after disturbance (Ervin and Wetzel, 2000). A very detailed review on autotoxicity, mainly in terrestrial plants, and its ecological significance was presented recently in this journal (Singh et al., 1999).

Autotoxicity was also reported for Typha latifolia (McNaughton, 1968). Phenolic compounds present in aqueous leachates from leaves completely inhibited seed germination in this species. However, autotoxicity was reevaluated 15 years later by Grace (1983), who could not confirm the earlier findings. Similar to J. effusus, antialgal secondary metabolites (sterols, fatty acids) have been isolated from T. latifolia (Aliotta et al., 1990; Della Greca et al., 1990). Aqueous extracts of leaves, stems, and roots of $T$. domingensis inhibited the growth of the water fern Salvinia minima in bioassays (Gallardo et al., 1998b). The most active phenolic compounds were 2-chlorophenol and salicylaldehyde, especially when extracted from roots. The concentration of these compounds was several micrograms per gram fresh mass of plant tissue (Gallardo et al., 1999). Recently, Gallardo-Williams et al. (2002) isolated several compounds from aqueous extracts and leachates of $T$. domingensis, among them linoleic and $\alpha$-linolenic acids and trace amounts of various phenolic acids. Linoleic and $\alpha$-linolenic acids have also been found in $T$. latifolia (Aliotta et al., 1990). These compounds are generally recognized to be phytotoxic; however, in the study by Gallardo-Williams et al. (2002) no bioassays with ecologically relevant concentrations were made. An annotated literature review of Typha, including citations on competitive abilities of this species, was provided by Gallardo et al. (1998a).

\section{Floating Leaved Macrophytes}

Both rooted and free-floating macrophytes have been included in this section. Rooted species obtain their nutrients predominantly from the sediment, and generally no nutrient competition with algae or epiphytes takes place. In contrast, freefloating macrophytes get all nutrients from the water, and may compete with phytoplankton or epiphytes. Floating leaved macrophytes grow only in stagnant waters, protected from wind or wave exposure. Few seedlings of other species can establish in extensive stands of rooted floating leaved macrophytes. Aqueous extracts of Nuphar lutea inhibited the growth of lettuce seedlings at low concentrations compared with 16 other macrophytes (Elakovich and Wooten, 1991; Elakovich and Wooten, 1995). Osmotic effects or changes in $\mathrm{pH}$ due to extract addition were ruled out in these assays. Alkaloids were considered responsible for the allelopathical activity (Elakovich and Yang, 1996). However, active concentrations used in the Lemna bioassay were too high for ecological relevance ( 2 ppm equivalent to approx. $4 \mathrm{mM}$ ). Aqueous leaf extracts and whole seedlings of Nelumbo lutea exhibited no allelopathic activity against the submerged macrophytes Myriophyllum spicatum and Potamogeton pectinatus (Vance and 
Francko, 1997). In exudates of Nuphar lutea, resorcinol was found in relatively high concentrations (Sütfeld et al., 1996). Some cryptophycean algae apparently polymerized resorcinol, but died after prolonged exposure (Sütfeld, 1998). Cyanobacteria and chlorophytes were not inhibited (Sütfeld et al., 1996).

Eichhornia crassipes is a dominant free-floating macrophyte in many tropical and subtropical lakes and waterways. Eichhornia may spread very fast and cause deleterious effects to lakes and waterways (Center et al., 1989; Mehra et al., 1999). Low phytoplankton densities may occur in these systems, either due to nutrient or light competition or the exudation of allelopathically active compounds. An axenic culture of Eichhornia was established, which allowed a controlled testing of exudates. Water, in which $E$. crassipes seedlings were cultivated, inhibited the growth of Chlamydomonas reinhardtii (Sun et al., 1990). Axenic as well as nonaxenic root exudates contained $N$-phenyl-1-naphthylamine and $N$-phenyl-2-naphthylamine; both highly algicidal compounds (Sun et al., 1993). Additionally, several phenalene metabolites have been isolated (Della Greca et al., $1992 b ; 1992 c)$. However, their allelopathic activity in vitro against several algae was low. A benzoindenone isolated from plant tissue was shown to inhibit Candida albicans. (Della Greca et al., 1991). Eichhornia itself was susceptible to allelopathic inhibition by residues and aqueous extracts of Parthenium hysterophorus (Asteraceae) (Pandey et al., 1993a; 1993b; Pandey, 1996). However, the concentrations of Parthenium allelochemicals needed for a deleterious effect in situ have been very high. Aqueous leachates of the terrestrial plant Lantana camara (Verbenaceae) killed Eichhornia when added to the culture medium (Saxena, 2000).

Pistia stratiotes is another free-floating macrophyte causing severe problems in many inland waters. Water lettuce, as it is also called, contains lipophilic algicidal compounds, among them $\alpha$-asarone, various fatty acids, and steroid derivatives (Aliotta et al., 1991). Two unusual hydroxy fatty acids were especially inhibitory. They may have originated from lipoxygenase oxidation of $\alpha$-linolenic acid. The inhibitory activity of linoleic and $\gamma$-linolenic acid; however, is probably due to the formation of hydroperoxide derivatives in the bioassay (Aliotta et al., 1990; Aliotta et al., 1991).

Potamogeton natans, a species with both floating-leaved and submersed leaves, produces various diterpenes with antialgal activity (Cangiano et al., 2001; Della Greca et al., 2001a; Cangiano et al., 2002). These studies are not explicit whether only floating leaves were used; such leaves emerge only after submersed leaves are decomposed. Most other Potamogetonaceae live fully submersed and exhibit no or only very weak allelopathic activity (personal observation). Hasler and Jones (1949) are sometimes cited for allelopathy in Potamogeton; however, in this study only small amounts of $P$. foliosus grew together with Elodea (Anacharis) canadensis. The latter exhibits allelopathic activity (Erhard and Gross, unpublished results).

\section{Submersed Macrophytes}

The major limiting resource for submersed macrophytes is shading by epiphytes and phytoplankton, or turbidity caused by sediment resuspension or humic compounds (Sand-Jensen, 1990). Effective defensive traits may include fast apical growth, canopy formation and the release of allelopathically active compounds. Evidence from field studies shows that allelopathy may be involved in macrophyte-microphyte interactions (Phillips et al., 1978; Scheffer et al., 1993). However, in situ no direct proof has been possible so far. Thus, we have to extrapolate from laboratory and mesocosm studies to investigate the ecological and evolutionary impact of allelopathy in this system.

Ceratophyllum demersum, a nonrooting, canopy-forming submersed angiosperm, showed allelopathic activity toward phytoplankton (Kogan and Chinnova, 1972; Wium-Andersen et al., 1983; Jasser, 1994; Jasser, 1995). Sulfur or a lipophilic, labile sulfur compound have been described as the major algicides in lipophilic extracts (WiumAndersen et al., 1983). Later studies showed that intact $C$. demersum released allelopathically active compounds inhibiting especially cyanobacteria (Jasser, 1994). Exudates caused species-specific allelopathic effects on various freshwater algae and cyanobacteria (Körner and Nicklisch, 2002). In a 
series of shallow eutrophic Norwegian lakes, $C$. demersum hampered phytoplankton development (Mjelde and Faafeng, 1997). The dominance of $C$. demersum in these lakes could best be explained by competition for nitrogen with phytoplankton. Ceratophyllum spp. appeared to be sensitive to allelopathic interference by Hydrilla verticillata (Kulshretha and Gopal, 1983). However, the active compounds of this interaction have not been identified.

Members of the genus Myriophyllum (Haloragaceae) are highly competitive submersed macrophytes (Grace and Wetzel, 1978; Smith and Barko, 1990; Madsen et al., 1991; Weisner et al., 1997). Many studies report their allelopathic activity against algae and cyanobacteria (Fitzgerald, 1969; Planas et al., 1981; Agami and Waisel, 1985; Saito et al., 1989; Aliotta et al., 1992; Gross et al., 1996; Nakai et al., 2000). Several phenolic compounds with algicidal activity against cultured algae and natural phytoplankton assemblages have been isolated from M. spicatum (Planas et al., 1981). The cyanobacterium Synechocystis [Anacystis] nidulans was most sensitive compared with the chlorophytes Selenastrum and Scenedesmus. In a later study $M$. spicatum, grown in mesocosms, stimulated phytoplankton growth (Godmaire and Planas, 1986). Nutrients or light did not account for higher phytoplankton productivity, suggesting that other, not yet identified factors caused this effect. Whether this is an example of stimulatory allelopathy remains to be elucidated.

Gallic, ellagic, and tannic acid were isolated from $M$. spicatum tissue after acid hydrolysis and shown to inhibit phytoplankton species (Planas et al., 1981). The presence of these phenolic compounds already indicated that hydrolyzable polyphenols might be responsible for the allelopathic interaction. Tellimagrandin II and other hydrolyzable polyphenols were later identified as the major algicidal compounds (Gross and Sütfeld, 1994; Gross et al., 1996). M. spicatum contains 10 to $25 \%$ polyphenols based on dry weight in leaves or apical meristem (Gross, 2000; Gross, unpublished results). This is much higher than concentrations of phenolic compounds observed in submersed macrophytes of other families (Gross, 1999; Smolders et al., 2000; Choi et al., 2002). Tellimagrandin II, also known as eugeniin (see Haslam, 1989; Gross, 1999), is also the major algicidal compound with strong activity against bloom-forming cyanobacteria in $M$. brasiliense, a South American partly emergent aquatic angiosperm (Saito et al., 1989). Planas (1981) described 3,5-dimethoxy-4-hydroxycinnamic acid (sinapic or sinapinic acid) to be present in high concentrations in $M$. spicatum. Algicidal esters of sinapic (sinapinic) acid, other phenylpropanoic acids and gallic acid were isolated from $M$. verticillatum by Aliotta et al. (1992). Extracts of $M$. spicatum exhibited the strongest inhibitory activity toward Selenastrum capricornutum and Microcystis aeruginosa compared with extracts from Egeria densa and Cabomba caroliniana (Nakai et al., 1996). M. spicatum actively releases allelochemicals to the environment (Gross et al., 1996), but the allelochemicals are readily metabolized after exudation (Gross et al., 1996; Gross, 1999), and a continuous release is required for the algicidal activity (Nakai et al., 1999). Tellimagrandin II, ellagic acid, and several other not yet identified low molecular polyphenols have been found in exudates of this plant (Gross and Sütfeld, 1994). Similar results have been reported by Nakai et al. (2000), who found gallic, pyrogallic, and ellagic acid as well as (+)-catechin in exudates. Gallic and pyrogallic acids were more inhibitory toward Microcystis aeruginosa than ellagic acid and (+)-catechin. Glomski et al. (2002) recently doubted that exudation of polyphenols by $M$. spicatum occurs to any significant amount. However, their method was not adjusted to optimal trapping of polyphenols, and no exact concentrations of plants used in the exudation experiment were provided.

\section{B. Macroalgae}

The most prominent macroalgae in freshwater (and brackish) systems are charophytes (Characeae, Nitellaceae). Chara-dominated lakes are generally clear and exhibit low phytoplankton densities (Crawford, 1977; van den Berg et al., 1998). Multiple factors may account for this, for example, reduced sediment resuspension, competition for nutrients, and refuge for herbivorous zooplankton (Scheffer et al., 1993; van Donk and 
van de Bund, 2002). In addition, allelopathy was frequently considered as an adaptive trait of Chara to prevent dense phytoplankton and epiphyte development. Bioactive cyclic sulfur compounds have been isolated from Chara globularis (Anthoni et al., 1980) and other brackish and freshwater Chara species (Wium-Andersen et al., 1982). These compounds are very labile and may release sulfur after decay. Whether the cyclic sulfur compounds, their presumed precursors in the plant, or sulfur itself caused the inhibition of photosynthesis in phytoplanktonic algae has never been resolved (Wium-Andersen et al., 1982; WiumAndersen, 1987). The ecological significance of these laboratory findings with extracted material has been debated. Based on the relation of phytoplankton chlorophyll to phosphorus concentration in Chara-dominated and Chara-free lakes, Forsberg et al. (1990) argued that allelopathy is unlikely to be of ecological importance in situ. Lack of allelopathic activity might be due to nonallelopathic Chara species present in these lakes. Ch. globularis, the only species with prominent allelopathic activity (Wium-Andersen et al., 1982), was not dominant but Ch. tomentosa (Forsberg et al., 1990); other occurring species were $C h$. contraria, Ch. vulgaris, and Ch. aspera. Laboratory studies revealed that only exudates of Chara globularis significantly limited microalgal growth, exudates of Ch. tomentosa, Ch. delicatula, or Ch. hispida either had no or stimulatory effects on Scenedesmus (Hootsmans and Blindow, 1994). These findings indicate that the release of allelopathically active compounds in Chara is species specific. They further point out that such effects might be possible in situ. However, we are still lacking conclusive field evidence for the proposed allelopathic activity of Chara. New evidence for allelopathy in Chara was provided recently by van Donk and van de Bund (2002).

Tuft-forming Cladophora species are frequent both in running and stagnant waters. They can form big mats, competing with other macroalgae or macrophytes for light and space. They also suffer from dense epiphyte cover. Extracts of C. glomerata lowered the photosynthetic rates of epiphytic Nitzschia sp. (Dodds, 1991). Low epiphyte densities were also found on Spirogyra and may be related to tannin-like compounds present in viable cells of this macroalga (Pankow, 1961; also see Section IV.A). Furthermore, positive allelopathic interactions were described for Spirogyra. Aqueous extracts stimulated growth and microcystin production in Oscillatoria agardhii (Mohamed, 2002). Oscillatoria formed only blooms in irrigation channels when Spirogyra was present.

\section{Microalgae}

Only few recent studies reveal allelopathic interactions of freshwater microalgae. Inderjit and Dakshini (1994) published a review on algal allelopathy. Many algae or cyanobacteria produce a distinct pattern of volatile organic compounds (VOC). Their ecological role is largely unknown. To test whether they are allelopathically active, various VOC commonly found in cyanobacteria and algae were used as synthetic compounds in an agar diffusion assay, and they inhibited Chlorella pyrenoidosa (Ikawa et al., 2001). However, the concentrations needed were extremely high (up to $10 \mathrm{mg} / \mathrm{ml}$, equivalent to the $\mathrm{m} M$ range), and the bioassay design does rather implicate a direct effect on the cells and not via airborne chemicals.

In contrast to marine dinoflagellates, those living in freshwater are generally considered to be nontoxic and harmless algae. Peridinium gatunense, a bloom-forming dinoflagellate in Lake Kinneret, Israel, influences toxin production in Microcystis sp., bloom-forming cyanobacteria in this lake (Vardi et al., 2002, and see Section III.D). $P$. bipes was also shown to have an algicidal effect on $M$. aeruginosa (Wu et al., 1998). $P$. aciculiferum caused cell lysis of the cryptophyte Rhodomonas lacustris (Rengefors and Legrand, 2001). This cryptophyte is a naturally co-occurring competitor for $P$. aciculiferum. The authors suggest that allelopathy in this dinoflagellate is an adaptive strategy to outcompete other winter phytoplankton.

\section{Cyanobacteria}

Cyanobacteria may be dominant in both pelagic and benthic freshwater habitats. They can 
produce effective allelochemicals interfering with the growth of competing cyanobacteria and algae. The control of photoautotrophic biofilms by allelopathic interactions was recently reviewed by Jüttner (1999), with special emphasis on benthic cyanobacteria. Further references are given in Gross (1999). Bloom-forming pelagic cyanobacteria are well known for their neuro- or hepatotoxic metabolites (Ostensvik et al., 1998; Skulberg, 2000; Kaebernick and Neilan, 2001). The ecological role of these cyanotoxins, especially with regard to allelopathy, is debated. The dominance of a colonial cyanobacterium in an acidic Swedish lake, Merismopedia tenuissima, was thought to depend on allelopathical control of other phytoplankton species (Blomqvist, 1996). Because not much is known on allelopathic interactions of bloom-forming cyanobacteria, I have included all available studies on the potential allelopathic activity of cyanotoxins in this review. Reference to allelopathically active nonbloom-forming or benthic cyanobacteria is provided in this section and in Section IV.B.

The benthic cyanobacterium Scytonema hofmannii produces cyanobacterin, an effective allelochemical-inhibiting cyanobacteria (Gleason and Paulson, 1984), eukaryotic algae (Gleason and Baxa, 1986), and higher plants (Gleason and Case, 1986). A second chlorinated aromatic compound with algicidal activity was later isolated from this cyanobacterium (Lee and Gleason, 1994). No further reports on halogenated secondary metabolites in freshwater cyanobacteria exist to date. The mode of action of these lipophilic, low-molecular-weight secondary metabolites is inhibition of photosystem II (see Section IV.B). Cyanobacterin is toxic to a variety of higher plants when applied as spray on the leaves but not via root uptake (Gleason and Case, 1986). The floating macrophyte Lemna gibba was severely inhibited when cyanobacterin was added in concentrations as low as $2.3 \mu M$ to the cultivation medium (Gleason and Case, 1986).

Members of the genus Fischerella (especially $F$. ambigua and F. muscicola), benthic cyanobacteria, exhibit allelopathic activity toward many cyanobacteria and eukaryotic algae, but almost none against bacteria. $F$. muscicola UTEX 1829 was the most active strain in a screening of 65 filamentous, nitrogen-fixing cyanobacteria for cyanobactericidal compounds (Flores and Wolk, 1986). Fischerella strains were also the most active species in a screening of new cyanobacterial isolates from Australia and Asia for allelopathy against chlorophytes and cyanobacteria (Schlegel et al., 1998). F. muscicola apparently produces cyanobactericidal metabolites at all growth stages (Srivastava et al., 1999). The major inhibitor fischerellin A was isolated (Gross et al., 1991), and its structure identified to contain an enediyne moiety and two heterocyclic ring systems (Hagmann and Jüttner, 1996). Other minor compounds with similar chemical and physiological characteristics are present in Fischerella (e.g., fischerellin B), which has only one heterocyclic ring and a similar side chain as fischerellin A (Papke et al., 1997). The alkaloids 12-epihapalindole $\mathrm{E}$ isonitrile from Fischerella and calothrixin A from Calothrix inhibited RNA synthesis of various organisms (Doan et al., 2000), indicating another mode of action for allelopathically active secondary metabolites in cyanobacteria.

Exudates of the filamentous cyanobacterium Trichormus doliolum inhibited other cyanobacteria and some chlorophytes (von Elert and Jüttner, 1996). The inhibition was enhanced when the donor species was kept in phosphorus limitation, and target species were more susceptible to inhibition under light limitation. Allelochemicals in exudates from phosphorus-limited $T$. doliolum cultures inhibited Anabaena variabilis ATCC 29413 even when the biomass of this target species was 20-fold greater (von Elert and Jüttner, 1997).

Oscillatoria sp. produced and released allelopathically active compounds inhibiting other cyanobacteria and chlorophytes but not heterotrophic organisms (Chauhan et al., 1992; Bagchi et al., 1993). Later, a lipophilic low molecular inhibitor of photosystem II from Oscillatoria late-virens was isolated (Bagchi et al., 1993; Bagchi, 1995). Nutrients interfered with the production of these allelopathically active compounds (Ray and Bagchi, 2001). Nostoc linckia produced and released another allelochemical named cyanobacterin LU-1 that inhibited the growth of many cyanobacteria and eu- 
karyotic algae but not heterotrophic bacteria and fungi (Gromov et al., 1991). Nostoc strain 31 produces cyclic heptapeptides, nostocyclamide and nostocyclamide $M$, which are allelopathically active against cyanobacteria and algae (Todorova and Jüttner, 1995; Jüttner et al., 2001).

Several bloom-forming, pelagic cyanobacteria produce cyanotoxins, neurotoxins such as anatoxin and hepatotoxins such as microcystins (see Carmichael, 1992; Skulberg, 2000). These toxins act primarily on vertebrates, and there is little evidence that intact cells release these compounds in significant concentrations to the surrounding medium. The physiological, ecological, and evolutionary aspects of cyanotoxin production for the producing cyanobacteria is not well known (Kaebernick and Neilan, 2001), although some reports indicate allelopathic activity in Microcystis (Lam and Silvester, 1979), and see Maestrini and Bonin (1981) for discussion. Chlorella pyrenoidosa was inhibited by lipids from Microcystis aeruginosa (Ikawa et al., 1996). The compounds responsible for the observed allelopathic effect were linoleic and linolenic acid. Other studies caution against the bioactivity of these fatty acids, since they may oxidize during the bioassay procedure (Aliotta et al., 1990; Aliotta et al., 1991).

Recently, anatoxin and microcystin LR from Anabaena flos-aquae were reported to be involved in chemical signaling between competing phytoplankton organisms, that is, A. flos-aquae and Chlamydomonas reinhardtii, a flagellated unicellular chlorophyte (Kearns and Hunter, 2000; Kearns and Hunter, 2001). Extracellular products of A. flos-aquae inhibited the growth of C. reinhardtii but not vice versa. Microcystin LR but not anatoxin used as purified compound inhibited growth of the chlorophyte. $C$. reinhardtii and the extracellular products of this chlorophyte had no impact on microcystin LR, but significantly increased the anatoxin content in A. flosaquae (Kearns and Hunter, 2000). Motility and settling rate of $C$. reinhardtii were temporarily increased in the presence of purified cyanotoxins or extracellular products from A. flos-aquae (Kearns and Hunter, 2001). However, there is some inconsistency in the two studies concerning the extracellular concentration of the cyanotoxins, and at present it may as well be that other, not yet identified allelochemicals in the exudates of $A$. flos-aquae are responsible for the inhibition of motility and growth in $C$. reinhardtii. Exudates from $C$. reinhardtii inhibited heterocyst formation in A. flos-aquae (Kearns and Hunter, 2002)

Allelopathic activity of an unidentified microcystin was suggested by Singh et al. (2001). Photosynthetic oxygen evolution, ${ }^{14} \mathrm{CO}_{2}$-carbon uptake and nitrogenase activity of Nostoc muscorum and Anabaena BT1 were inhibited in concentrations of 25 to $300 \mu M$ by a compound strongly resembling microcystin LR based on TLC and HPLC findings. No final identification of the active compound was made. The concentration of the microcystin-like compound used was, however, at the upper limit of or even above microcystin concentrations found in German lakes (Fastner et al., 1999). Microcystin LR was considered allelopathically active against various submersed macrophytes (Pflugmacher, 2002). Kasumigamide, a tetrapeptide isolated from $M$. aeruginosa, inhibited green algae at concentrations of approx. $2.5 \mathrm{mM}$ (MIC), thus also well above possible natural concentrations (Ishida and Murakami, 2000).

A novel allelopathic mode of action was discovered recently whereby exudates from Microcystis inhibited photosynthesis of the dinoflagellate Peridinium gatunense by interference with its internal carbonic anhydrase activity (Sukenik et al., 2002). Microcystin LR is apparently not responsible for this action, since this mechanism occurred also with strains not producing this heptapeptide. Exudates also induced oxidative stress in $P$. gatunense and activated certain protein kinases (Vardi et al., 2002). Interestingly, both Microcystis and $P$. gatunense exerted reciprocal, density-dependent allelopathic activity. In the presence of $P$. gatunensis, Microcystis cells lost buoyancy, followed by cell lysis and a dramatic increase of McyB, a subunit of the peptide synthetase complex involved in microcystin biosynthesis (Vardi et al., 2002). These two species might be a highly interesting model system for aquatic allelopathy: both occur in the same lake, exudates exerted the allelopathic activity, and the modes of action could be identified using modern physiological and molecular techniques. 


\section{MODES OF ACTION}

Allelochemicals can interfere with many processes of target organisms (see, e.g., Reigosa et al., 1999; Einhellig, 2001). From the above-mentioned studies it is apparent that allelopathically active compounds are often directed at two physiological processes, photosynthesis and enzyme activity. Only those are considered in detail in the following.

\section{A. Inhibition of Enzymes}

Enzyme function is essential for all organisms. Many aquatic organisms produce extracellular enzymes that enable them to use complex substrates or are involved in the colonization of surfaces (Chróst, 1991; Wetzel, 1991). Interference with these enzymes can alter competitive interactions among organisms, change the settling of organisms, and interfere with biofilm formation and/or epiphyte growth.

Many microalgae and cyanobacteria produce glycosidase (Cannell et al., 1987) and protease inhibitors (Cannell et al., 1988b), some are released into the culture medium. Approximately $20 \%$ of all isolates of filamentous cyanobacteria from biofilms in Taiwan possessed $\alpha$-glucosidase inhibitory activity, as well as allelopathic activity and grazer toxicity (Jüttner and $\mathrm{Wu}, 2000$ ). Pentagalloylglucose was identified as the major inhibitor of $\alpha$-glucosidase from the chlorophyte Spirogyra varians (Cannell et al., 1988a). Further, tetra- to undecagallotannins were isolated from Spirogyra at concentrations of 2 to $6 \%$ of the dry mass (Nishizawa et al., 1985). Most hydrolyzable polyphenols effectively complex proteins, and thus might inhibit enzymes (Haslam, 1989). The occurrence of hydrolyzable polyphenols in chlorophytes is limited to species belonging to the 'phragmoplast' group (see Sawitzky and Grolig, 1995; Pickett-Heaps et al., 1999) such as Spirogyra. Tannins are stored in vacuoles of this filamentous chlorophyte, comparable to higher plants. Another extracellular, low-molecular-weight $\alpha$-amylase inhibitor was isolated from Anabaena flos-aquae (Winder et al., 1989).
Tellimagrandin II and other hydrolyzable polyphenols present in and released by the freshwater submersed angiosperm Myriophyllum spicatum are effective inhibitors of alkaline phosphatase (Gross and Sütfeld, 1994; Gross et al., 1996; Gross, 1999). The inhibitory activity of complex polyphenols was much larger than comparable amounts of the simple phenolic compound gallic acid (Gross et al., 1996).

\section{B. Allelochemicals Affecting Photosynthesis}

The inhibition of photosynthesis, the central physiological process of competing primary producers, is an effective defense strategy of many aquatic angiosperms, algae, and cyanobacteria. Methods used by several authors to investigate the impact of allelochemicals on photosynthesis focus either on measuring oxygen evolution with Clark-type electrodes, or carbon incorporation with the radiocarbon method. The former allows a more detailed study of the site of inhibition because artificial electron acceptors and donors allow a decoupling of photosystem I and II (PSI and PSII), and comparison with known synthetic herbicides. These studies indicate that the majority of the allelochemicals interfere with PSII. However, in most cases they act at different sites than most synthetic herbicides, whose primary target is the quinone-B binding site (Trebst et al., 1984; Ohad and Hirschberg, 1990; Huppatz, 1996). This confirms that natural herbicides exhibit a wider range of target sites than synthetic inhibitors (Duke et al., 2001).

\section{Cyanobacteria}

A recent review summarized allelochemicals affecting photosynthesis produced by cyanobacteria (Smith and Doan, 1999), indicating that this mode of action is widespread among cyanobacteria. Conversely, in a large screening of cyanobacteria, Schlegel et al. (1998) concluded that bioactivity directed against algal photosynthesis might be relatively rare because of differential effects observed under photoautotrophic or heterotrophic conditions. 
Yet, no direct measurements of photosynthetic electron transport were made in this study. Lipophilic inhibitors produced by benthic cyanobacteria are best investigated for their impact on photosystem II of other cyanobacteria and algae. Cyanobacterin from Scytonema hofmannii (Pignatello et al., 1983) inhibits PSII at the oxidizing site of the quinone-B electron acceptor, but not at the site where DCMU (3-(3,4-dichlorphenyl)-1,1-dimethylurea) interacts with PSII (Gleason and Paulson, 1984; Gleason and Baxa, 1986; Gleason and Case, 1986; Gleason et al., 1986). Electron microscope studies revealed that cyanobacterin also specifically disrupted the thylakoid membrane structure in Euglena gracilis (Gleason, 1990). These findings show that allelopathically active compounds may have multiple modes of action, as was postulated before (Einhellig, 1995; Einhellig, 2001).

Fischerellin A isolated from Fischerella muscicola inhibited PSII (Gross et al., 1991; Srivastava et al., 1998) and acted at four different sites in PSII with different times of interaction (Srivastava et al., 1998). PSII of cyanobacteria and eukaryotic algae but not of purple bacteria was affected by fischerellin A. Many other cyanobacteria inhibit photosynthesis, and some of the allelochemicals involved act specifically on PSII. Examples are allelochemicals released by Trichormus doliolum (von Elert and Jüttner, 1997) or the inhibitor isolated from Oscillatoria late-virens (Bagchi, 1995).

\section{Macrophytes}

Aqueous extracts, possibly including phenolic allelochemicals, from the marine angiosperm Zostera marina decreased the primary production of epiphytic diatoms (Harrison and Durance, 1985). For freshwater systems, the cyclic sulfur compounds dithiolane and trithiane from Chara globularis are the best known allelochemicals affecting carbon uptake by cultured diatoms and natural phytoplankton assemblages (WiumAndersen et al., 1982). In a later study, the same author proposed that a labile sulfur compound in Ceratophyllum demersum was responsible for the observed reduction in primary productivity and concluded that elemental sulfur released from these labile compounds might be the ultimate cause (Wium-Andersen et al., 1983). Whether sulfur is also the effective allelochemical in Chara has never been investigated. Exudates of $C$. demersum inhibited PSII but not growth of algae and cyanobacteria (Körner and Nicklisch, 2002).

Extracts and exudates from Myriophyllum spicatum inhibit photosynthesis of various cyanobacteria, chlorophytes, and diatoms (Körner and Nicklisch, 2002; Leu et al., 2002). Using dialysis membranes and controlling for nutrient competition, Körner and Nicklisch (2002) showed that $M$. spicatum causes species-specific effects in a range of cyanobacteria, chlorophytes, and diatoms and inhibits both growth and PSII in natural relevant concentrations. The mechanism of interference with PSII was studied in detail by Leu et al. (2002). Lipophilic extracts and purified tellimagrandin II interfered with photosynthetic electron transport of the cyanobacterium Anabaena sp. PCC 7120. Tellimagrandin II and/or other polyphenols in $M$. spicatum probably cause a higher redox midpoint potential for the nonheme iron, located between the primary and the secondary quinone electron acceptors, $\mathrm{Q}_{\mathrm{A}}$ and $\mathrm{Q}_{\mathrm{B}}$ in PSII. This mode of action is different from those of synthetic herbicides, apparently a common characteristic of many natural herbicides (Duke et al., 2000).

\section{BACTERIAL MEDIATION/BIOFILM}

From the above-mentioned studies it is apparent that many allelopathic interactions in aquatic systems occur surface-associated, either in benthic communities or between photoautotrophs and their epiphytes. Benthic algal or cyanobacterial mats and epiphytic communities are complex systems, differing, for example, in stratification or recycling capacity (Peterson and Tuchman, 1992; Wetzel, 1993). Biofilms are formed through a complex succession of organisms, usually starting with carbohydrates, followed by bacteria, photoautotrophs, and animals (Wahl, 1989). Microorganisms, thus bacteria and fungi, are explicitly incorporated in the original definition of allelopathy by Molisch (1937). However, we have only little insight into the role of bacteria 
in allelopathic interactions of aquatic primary producers. The following section presents some information on allelopathic interference between bacteria and aquatic photoautotrophs.

Several cyanobacteria produce antibiotic compounds against heterotrophic bacteria (Borowitzka, 1995; Ostensvik et al., 1998; Kreitlow et al., 1999; Skulberg, 2000). Some planktonic cyanobacteria (Aphanizomenon flos-aquae, Cylindrospermopsis raciborskii, Microcystis aeruginosa, Tychonema bourrellyi) exhibited extractable antibiotic activity in various bioassay systems (Ostensvik et al., 1998). A strain of Phormidium produced extracellular antimicrobial compounds inhibiting a wide range of Gram-positive and Gram-negative heterotrophic bacteria (Fish and Codd, 1994b).

Although bacteria do not compete with cyanobacteria for light or most nutrients, they may enhance attachment of other primary producing microalgae on benthic cyanobacterial mats. Nostoc muscorum produced antibiotic and antifungal compounds of medium molecular weight $\left(M_{r} 2000\right.$ to 3000) (Bloor and England, 1989). The release of these compounds into the culture medium was controlled by nitrate and iron (Bloor and England, 1991). However, it has never been investigated whether these antibiotic compounds are ecologically relevant in preventing or delaying the development of biofilms. Direct interactions between bacteria and certain cyanobacteria have been described. Bacteria co-occurring with Microcystis aeruginosa exhibited a higher attractance to this cyanobacterium than to other cyanobacteria and were less inhibited by exudates (Casamatta and Wickstrom, 2000). The marine bacterium $P$ seudoalteromonas tunicata effectively inhibited algal spore germination through extracellular inhibitors (Egan et al., 2001a; Egan et al., 2001b). Some marine fungi growing epiphytically on the surface of macroalgae produce algicidal compounds inhibiting the growth of microalgae (Chen et al., 1996; Jenkins et al., 1998). Hence, in some instances not the host plant itself but associated microorganisms account for allelopathic effects.

To avoid bacterial metabolization of allelochemicals, many studies use axenic organisms. Axenic [Greek] meaning "without strangers" was originally coined as term by Baker and
Ferguson (1942). Bacterial metabolization of allelochemicals released by plants happens frequently. Juglone would not be active without the glycosidase activity of soil bacteria. Non-axenic Fischerella tisserantii (Cyanobacteria) contained lower concentrations of fischerellin A compared with the axenic strains $F$. ambigua and $F$. muscicola (Gross et al., 1991; Gross, unpublished results). Exudates of Myriophyllum spicatum loose their inhibitory activity on algae and cyanobacteria over time, indicating bacterial degradation (Gross et al., 1996; Nakai et al., 1999).

\section{ABIOTIC INTERFERENCE}

\section{A. Nutrient Stress}

Allelopathy is considered to be especially effective in stress situations (Reigosa et al., 1999), for example, under nutrient limitation. Target organisms might be more susceptible to allelochemicals under stress, and/or donor organisms might induce or augment the production of allelopathically active compounds under such conditions.

In the soft coral Sarcophyton ehrenbergi (Octocorallia: Acyonaceae) the ratio of allelochemicals to lipids was strongly influenced by the nutrient status of the tissue (Fleury et al., 2000). The active compounds are cembranoid diterpenes, some of which are ichthyotoxic and others may be involved in allelopathic interactions (see Section II.E). Increased nitrogen availability leads to higher ratios, whereas under surplus phosphorus the ratio declined compared with nutrient saturation. At times of greatest coral growth, more nitrogen resulted in more biomass production of the zooxanthellae and less transfer of metabolites to the coral. In response, the terpenoid biosynthesis of the latter increased (Fleury et al., 2000).

Fitzgerald (1969) recognized that nitrogen limitation but not phosphorus limitation caused a decline in epiphyte growth on various macroalgae and aquatic angiosperms. He considered either a "nitrogen sink" effect or antagonistic (allelopathic) interference to be responsible for the inhibition of epiphytes in cultures of Myriophyllum sp., Ceratophyllum sp., Lemna minor, Cladophora sp., and Pithophtora oedogonium. Myriophyllum, the 
only rooted species in this list, can take up nitrogen both with shoots and roots, depending on the concentrations in the respective compartments (Nichols and Keeney, 1976a). All others obtain nitrogen primarily from the water. Ceratophyllum demersum appeared to act as a nitrogen sink, especially in spring (Mjelde and Faafeng, 1997): Many clearwater shallow Norwegian lakes exhibiting low phytoplankton densities, high phosphorus concentrations but indication of nitrogen limitations were dominated by $C$. demersum. Unfortunately, allelopathy was not investigated in this study.

Nutrients frequently interfere with the allelopathic activity of cyanobacteria (von Elert and Jüttner, 1996; von Elert and Jüttner, 1997; Ray and Bagchi, 2001). Phosphorus limitation of phytoplankton and epiphytes during summer is common in many freshwater lakes, even when the lake is eutrophic (Vrba et al., 1993). Polyphenolic allelochemicals present in Myriophyllum spicatum interfere with alkaline phosphatase, an exoenzyme used by many algae and cyanobacteria to overcome inorganic phosphorus limitation (Gross et al., 1996; Gross, 1999). The macrophyte obtains phosphorus predominantly through the roots (Best and Mantai, 1978; Carignan and Kalff, 1980; Barko and Smart, 1981), but phytoplankton and epiphytes (Carignan and Kalff, 1982) rely on phosphorus in the water. Thus, the inhibition of alkaline phosphatase provides a competitive advantage for this submersed macrophyte. In contrast to marine systems, freshwater phytoplankton is seldom nitrogen limited (Weithoff and Walz, 1999; Wetzel, 2001). M. spicatum, yet, was frequently reported to be nitrogen limited (Nichols and Keeney, 1976b; Barko and Smart, 1986; Sytsma and Anderson, 1993). Algicidal polyphenols in $M$. spicatum are inversely related to tissue nitrogen (Gross, 1999; Gross, unpublished results). Especially active growing tissues (apical meristems) have high spring and summer levels of polyphenols, whereas in fall polyphenols decline and nitrogen tissue concentration increases. The differential responses of the donor organism (M. spicatum) and target organisms (phytoplankton, epiphytes) to phosphorus and nitrogen limitation strongly affects the allelopathic interactions in this system. Because nutrients often interfere with allelopathic interactions, Inderjit (1997) recently asked whether it is realistic to separate resource competition from allelopathy.

\section{B. Other Environmental Impacts}

The soft coral Sinularia flexibilis produces allelochemicals preventing the growth of bacteria and algae on its surface (Aceret et al., 1998). Bleaching caused a loss of zooxanthellae in this coral, and resulted in a short-term loss of the principal algicidal terpenoid sinulariolide to $8 \%$ compared with controls (Michalek-Wagner and Bowden, 2000). In contrast, the levels of the antibacterial secondary metabolite flexibilid more than doubled. Surprisingly, low levels of algicide did not result in increased algal growth on the surface of Sinularia (Michalek-Wagner and Bowden, 2000). Considering the succession of epibionts (see above Wahl, 1989), bacteria have to colonize first before algae will attach. In this context, stressed $S$. flexibilis would reallocate the secondary metabolites to the primary target of epibiosis (bacteria) and still get sufficient protection against algal overgrowth. More studies are needed to investigate the mutual effect of bacteria and algae in aquatic biofilms. Important insights are currently emerging from the study of the rhodophyte Delisea pulchra and its secondary metabolites that interfere with bacterial quorumsensing signals (Kjelleberg et al., 1997; Rice et al., 1999; Charlton et al., 2001; Steinberg et al., 2001).

Terrestrial humic compounds are frequently reported to disturb aquatic communities (phytoplankton, macroalgae, higher plants) both in marine and freshwater systems (Inderjit and Gross, 2002). Precipitation run-off from land to water is one possibility how terrestrial vegetation can impact aquatic primary producers. Lower run-off of forest humic compounds caused a shift in the macroalgal community structure from phaeophytes to crustose coralline rhodophytes on the coast of Japan. Laboratory experiments showed that allochthonous humic compounds inhibit crustose coralline spore germination and promoted phaeophyte oogonium formation, the latter probably through complexation of iron by fulvic acids (Matsunaga et al., 1999). 
After release, allelochemicals are subjected not only to biotic metabolisation but also to abiotic factors. Light, oxygen, and redox conditions might influence the stability of allelochemicals. Transformations such as oxidation, polymerization, or cleavage can take place. Ultraviolet radiation caused a different photoreactivity of leachates from two freshwater macrophytes (Farjalla et al., 2001).

\section{MATHEMATICAL MODELING}

Few authors have been modeling allelopathic interactions based on field or experimental data (Chao and Levin, 1981; Antonelli et al., 1993; Cheng, 1995; Mukhopadhyay et al., 1998; Tapaswi and Mukhopadhyay, 1999; An et al., 2002; An et al., 2003). Such studies generally have to simplify processes, which may not always be satisfactory. However, models can help to clarify patterns of species interactions and guide further experiments. Allelopathy among bacteria, that is, antibiotic activity, strongly differed whether they were grown in liquid culture or on agar, a two-dimensional, structured habitat (Chao and Levin, 1981; Wiener, 2000). On agar, allelochemical-producing Escherischia coli had an advantage over competing bacteria even at low initial densities (Chao and Levin, 1981). Allelopathic interactions in phytoplankton communities were modeled by Mukhopadhyay et al. (1998) and Tapaswi and Mukhopadhyay (1999). Their models are based on two species Lotka-Volterra competitive systems where both species had competitive and allelopathic interactions. Allelopathic interference between soft and scleractinian corals was described based on the mathematical theory of VolterraHamilton systems (Antonelli et al., 1993). Scleractinians had the highest survival when they took refuge in space and evaded direct toxic effects of soft corals. The model predicted no coevolution leading to the neutralization of the allelopathically active terpenes by the target organisms. This outcome is remarkable in the context of Reigosa et al. (1999), who hypothesized that allelopathy between species in one habitat is rare because of tolerance toward allelochemicals present in this system (see Section I.B).

\section{ACKNOWLEDGEMENTS}

I gratefully acknowledge helpful comments by Daniela Erhard, Doris Greilinger, Sabine Körner, and a detailed review by Friedrich Jüttner on a previous version of this manuscript.

\section{REFERENCES}

Abarzua, S., Jakubowski, S., Eckert, S., and Fuchs, P. 1999. Biotechnological investigation for the prevention of marine biofouling. II. Blue-green algae as potential producers of biogenic agents for the growth inhibition of microfouling organisms, Bot. Mar. 42: 459-465.

Aceret, T. L., Coll, J. C., Uchio, Y, and Sammarco, P. W. 1998. Antimicrobial activity of the diterpenes flexibilide and sinulariolide derived from Sinularia flexibilis Quoy and Gaimard 1833 (Coelenterata: Alcyonacea, Octocorallia), Comp. Biochem. Phys. C 120: $121-126$.

Aceret, T. L., Sammarco, P. W., and Coll, J. C. 1995. Toxic effects of alcyonacean diterpenes on scleractinian corals, J. Exp. Mar. Biol. Ecol. 188: 63-78.

Adachi, M., Kanno, T., Matsubara, T., Nishijima, T., Itakura, S., and Yamaguchi, M. 1999. Promotion of cyst formation in the toxic dinoflagellate Alexandrium (Dinophyceae) by natural bacterial assemblages from Hiroshima Bay, Japan, Mar. Ecol. Progr. Ser. 191: 175-185.

Adachi, M., Matsubara, T., Okamoto, R., Nishijima, T., Itakura, S., and Yamaguchi, M. 2002. Inhibition of cyst formation in the toxic dinoflagellate Alexandrium (Dinophyceae) by bacteria from Hiroshima Bay, Japan, Aquat. Microb. Ecol. 26: 223-233.

Agami, M. and Waisel, Y. 1985. Interrelationship between Najas marina $\mathrm{L}$. and three other species of aquatic macrophytes, Hydrobiologia 126: 169-173.

Al Hamdi, B., Inderjit, Olofsdotter, M., and Streibig, J. C. 2001. Laboratory bioassay for phytotoxicity: an example from wheat straw, Agron. J. 93: 43-48.

Aliotta, G., Della Greca, M., Monaco, P., Pinto, G., Pollio, A., and Previtera, L. 1990. In vitro algal growth inhibition by phytotoxins of Typha latifolia L., J. Chem. Ecol. 16: 2637-2646.

Aliotta, G., Molinaro, A., Monaco, P., Pinto, G., and Previtera, L. 1992. Studies on aquatic plants. 20. Three biologically active phenylpropanoid glucosides from Myriophyllum verticillatum, Phytochemistry 31: 109111.

Aliotta, G., Monaco, P., Pinto, G., Pollio, A., and Previtera, L. 1991. Potential allelochemicals from Pistia stratiotes L., J. Chem. Ecol. 17: 2223-2234.

An, M., Johnson, I. R., and Lovett, J. V. 2002. Mathematical modelling of residue allelopathy. the effects of intrinsic and extrinsic factors, Plant Soil 246: 11-22. 
An, M., Liu, D. L., Johnson, I. R., and Lovett, J. V. 2003. Mathematical modelling of allelopathy. II. The dynamics of allelochemicals from living plants in the environment, Ecol. Model. 161: 53-66.

Anthoni, U., Christophersen, C., Ogard Madsen, J., WiumAndersen, S., and Jacobsen, N. 1980. Biologically active sulphur compounds from the green alga Chara globularis, Phytochemistry 19: 1228-1229.

Antonelli, P. L., Sammarco, P. W., and Coll, J. C. 1993. A model of allelochemical interactions between soft and scleractinian corals on the Great Barrier Reef, J. Biol. Syst. 1: 1-17.

Arzul, G., Seguel, M., Guzman, L., and Denn, E. E.-L. 1999. Comparison of allelopathic properties in three toxic Alexandrium species, J. Exp. Mar. Biol. Ecol. 232: 285-295.

Bagchi, S. N. 1995. Structure and site of action of an algicide from a cyanobacterium, Oscillatoria late-virens, $J$. Plant Physiol. 146: 372-374.

Bagchi, S. N., Chauhan, V. S., and Marwah, J. B. 1993. Effect of an antibiotic from Oscillatoria laete virens on growth, photosynthesis, and toxicity of Microcystis aeruginosa, Curr. Microbiol. 26: 223-228.

Baker, J. A. and Ferguson, M. S. 1942. Growth of platyfish (Platypoecilus maculatus) free from bacteria and other microorganisms, Proc. Soc. Exp. Biol. Med. 51: 116 119.

Barko, J. W. and Smart, R. M. 1981. Sediment based nutrition of submersed macrophytes, Aquat. Bot. 10: 339 352.

Barko, J. W. and Smart, R. M. 1986. Sediment-related mechanisms of growth limitation in submersed macrophytes, Ecology 67: 1328-1340.

Best, M. D. and Mantai, K. E. 1978. Growth of Myriophyllum: Sediment or lake water as the source of nitrogen and phosphorus, Ecology 59: 1075-1080.

Blomqvist, P. 1996. Late summer phytoplankton responses to experimental manipulations of nutrients and grazing in unlimed and limed Lake Njupfatet, central Sweden, Arch. Hydrobiol. 137: 425-455.

Bloor, S. and England, R. R. 1989. Antibiotic production by the cyanobacterium Nostoc muscorum, J.Appl. Phycol. 1: 367-372.

Bloor, S. and England, R. R. 1991. Elucidation and optimization of the medium constituents controlling antibiotic production by the cyanobacterium Nostoc muscorum, Enzyme Microb. Tech. 13: 76-81.

Blum, U., Shafer, S. R., and Lehman, M. E. 1999. Evidence for inhibitory allelopathic interactions involving phenolic acids in field soils: concepts vs. an experimental model, Crit. Rev. Plant Sci. 18: 673-693.

Borowitzka, M. A. 1995. Microalgae as sources of pharmaceuticals and other biologically active compounds, $J$. Appl. Phycol. 7: 3-15.

Brix, H. and Sorrell, B. K. 1996. Oxygen stress in wetland plants: comparison of deoxygenated and reducing root environments, Funct. Ecol. 10: 521-526.
Cangiano, T., Della Greca, M., Fiorentino, A., Isidori, M., Monaco, P., and Zarrelli, A. 2001. Lactone diterpenes from the aquatic plant Potamogeton natans, Phytochemistry 56: 469-473.

Cangiano, T., Della Greca, M., Fiorentino, A., Isidori, M., Monaco, P., and Zarrelli, A. 2002. Effect of ent-labdane diterpenes from Potamogetonaceae on Selenastrum capricornutum and other aquatic organisms, J. Chem. Ecol. 28: 1091-1102.

Cannell, R. J. P., Farmer, P., and Walker, J. M. 1988a. Purification and characterization of pentagalloylglucose, an $\alpha$-glucosidase inhibitor antibiotic from the freshwater green alga Spirogyra varians, Biochem. I. 255: 937 941.

Cannell, R. J. P., Kellam, S. J., Owsianka, A. M., and Walker, J. M. 1987. Microalgae and cyanobacteria as a source of glucosidase inhibitors, J. Gen. Microbiol. 133: 1701-1705.

Cannell, R. J. P., Kellam, S. J., Owsianka, A. M., and Walker, J. M. 1988b. Results of a large scale screen of microalgae for the production of protease inhibitors, Planta Med. 54: 10-14.

Carignan, R. and Kalff, J. 1980. Phosphorus sources for aquatic weeds: water or sediments? Science 207: 987989.

Carignan, R. and Kalff, J. 1982. Phosphorus release by submerged macrophytes: significance to epiphyton and phytoplankton, Limnol. Oceanogr. 27: 419-427.

Carmichael, W. W. 1992. Cyanobacteria secondary metabolites - the cyanotoxins, J. Appl. Bacteriol. 72: 445459.

Casamatta, D. A. and Wickstrom, C. E. 2000. Sensitivity of two disjunct bacterioplankton communities to exudates from the cyanobacterium Microcystis aeruginosa Kützing, Microbial Ecol. 40: 64-73.

Center, T. D., Cofrancesco, A. F., and Balcunias, J. K. 1989. Biological control of aquatic and wetland weeds in the southeastern United States, in Delfosse, E. S., Ed., VII. Int. Symp. Biol. Contr. Weeds, Ist. Sper. Patol. Veg. (MAF), Rome, Italy, pp. 239262.

Chao, L. and Levin, B. R. 1981. Structured habitats and the evolution of anticompetitor toxins in bacteria, Proc. Natl. Acad. Sci. USA 78: 6324-6328.

Charlton, T., Givskov, M., deNys, R., Anderson, J. B., Hentzer, M., Rice, S., and Kjelleberg, S. 2001. Genetic and chemical tools for investigating signaling processes in biofilms, in Methods in Enzymology, Doyle, R. J., Ed., Academic Press, San Diego, pp. 108-128.

Chauhan, V. S., Marwah, J. B., and Bagchi, S. N. 1992. Effect of an antibiotic from Oscillatoria sp. on phytoplankters, higher plants and mice, New Phytol. 120: 251-257.

Chen, C., Imamura, N., Nishijima, M., Adachi, K., Sakai, M., and Sano, H. 1996. Halymecins, new antimicroalgal substances produced by fungi isolated from marine algae, J. Antibiot. 49: 998-1005. 
Cheng, H. H. 1995. Characterization of the mechanisms of allelopathy - modeling and experimental approaches, ACS Sym. Ser. 582: 132-141.

Choi, C., Bareiss, C., Walenciak, O., and Gross, E. M. 2002. Impact of polyphenols on the growth of the aquatic herbivore Acentria ephemerella (Lepidoptera: Pyralidae), J. Chem. Ecol. 28: 2223-2235.

Christensen, P. B., Revsbech, N. P., and Sand-Jensen, K. 1994. Microsensor analysis of oxygen in the rhizosphere of the aquatic macrophyte Littorella uniflora (L.) Ascherson, Plant Physiol. 105: 847-852.

Chróst, R. J. 1991. Microbial Enzymes in Aquatic Environments, Springer-Verlag, New York.

Corsaro, M. M., Della Greca, M., Fiorentino, A., Monaco, P., and Previtera, L. 1994. Cycloartane glucosides from Juncus effusus, Phytochemistry 37: 515-519.

Crawford, S. A. 1977. Chemical, physical and biological changes associated with Chara succession in farm ponds, Hydrobiologia 55: 209-217.

Dasneves, H. J. C. and Gaspar, E. M. M. 1990. Identification of active compounds in wheat straw extracts with allelopathic activity by HRGC-MS and HRGC-FTIR, HRC-J. High Res. Chrom. 13: 550-554.

de Nys, R., Coll, J. C., and Price, I. R. 1991. Chemically mediated interactions between the red alga Plocamium hamatum (Rhodophyta) and the octocoral Sinularia cruciata (Alcyonacea), Mar. Biol. 108: 315-320.

de Nys, R., Dworjanyn, S. A., and Steinberg, P. D. 1998. A new method for determining surface concentrations of marine natural products on seaweads, Mar. Ecol. Progr. Ser. 162: 79-87.

Della Greca, M., Monaco, P., Previtera, L., Aliotta, G., Pinto, G., and Pollio, A. 1989. Allelochemical activity of phenylpropanes from Acorus gramineus, Phytochemistry 28: 2319-2322.

Della Greca, M., Mangoni, L., Molinaro, A., Monaco, P., and Previtera, L. 1990. (20s)- $\alpha$-Methyl-24-methylenecholest7-en-3-B-ol, an allelopathic sterol from Typha latifolia, Phytochemistry 29: 1797-1798.

Della Greca, M., Lanzetta, R., Mangoni, L., Monaco, P., and Previtera, L. 1991. A bioactive benzoindenone from Eichhornia crassipes Solms, Bioorg. Med. Chem. Lett. 1: 599-600.

Della Greca, M., Fiorentino, A., Mangoni, L., Molinaro, A., Monaco, P., and Previtera, L. 1992a. 9,10-dihydrophenanthrene metabolites from Juncus effusus L., Tetrahedron Lett. 33: 5257-5260.

Della Greca, M., Lanzetta, R., Molinaro, A., Monaco, P., and Previtera, L. 1992b. Phenalene metabolites from Eichhornia crassipes, Bioorg. Med. Chem. Lett. 2: 311-314.

Della Greca, M., Molinaro, A., Monaco, P., and Previtera, L. 1992c. Dimeric phenalene metabolites from Eichhornia crassipes, Tetrahedron 48: 3971-3976.

Della Greca, M., Fiorentino, A., Mangoni, L., Molinaro, A., Monaco, P., and Previtera, L. 1993a. Cytotoxic 9,10dihydrophenanthrenes from Juncus effusus L., Tetrahedron 49: 3425-3432.
Della Greca, M., Fiorentino, A., Molinaro, A., Monaco, P., and Previtera, L. 1993b. A bioactive dihydrodibenzoxepin from Juncus effusus, Phytochemistry 34: 1182-1184.

Della Greca, M., Fiorentino, A., Monaco, P., and Previtera, L. 1994. Cycloartane triterpenes from Juncus effusus, Phytochemistry 35: 1017-1022.

Della Greca, M., Fiorentino, A., Monaco, P., Previtera, L., and Zarrelli, A. 1995. Effusides I-V - 9,10dihydrophenanthrene glucosides from Juncus effusus, Phytochemistry 40: 533-535.

Della Greca, M., Fiorentino, A., Monaco, P., Pinto, G., Pollio, A., and Previtera, L. 1996. Action of antialgal compounds from Juncus effusus $\mathrm{L}$. on Selenastrum capricornutum, J. Chem. Ecol. 22: 587-603.

Della Greca, M., Fiorentino, A., Monaco, P., Previtera, L., and Sorrentino, M. 1998. Antialgal phenylpropane glycerides from Juncus effusus, Nat. Prod. Lett. 12: 263-270.

Della Greca, M., Fiorentino, A., Isidori, M., Monaco, P., and Zarrelli, A. 2000a. Antialgal ent-labdane diterpenes from Ruppia maritima, Phytochemistry 55: 909-913.

Della Greca, M., Fiorentino, A., Monaco, P., Pollio, A., Previtera, L., and Zarrelli, A. 2000b. Dihydrophenanthrene and phenanthrene mimics of natural compounds - Synthesis and antialgal activity, J. Chem. Ecol. 26: 587-600.

Della Greca, M., Fiorentino, A., Isidori, M., Monaco, P., Temussi, F., and Zarrelli, A. 2001a. Antialgal furanoditerpenes from Potamogeton natans L, Phytochemistry 58: 299-304.

Della Greca, M., Fiorentino, A., Monaco, P., Pinto, G., Previtera, L., and Zarrelli, A. 2001b. Synthesis and antialgal activity of dihydrophenanthrenes and phenanthrenes II: Mimics of naturally occurring compounds in Juncus effusus, J. Chem. Ecol. 27: 257-271.

Della Greca, M., Fiorentino, A., Isidori, M., Lavorgna, M., Monaco, P., Previtera, L., and Zarrelli, A. 2002a. Phenanthrenoids from the wetland Juncus acutus, Phytochemistry 60: 633-638.

Della Greca, M., Fiorentino, A., Monaco, P., Previtera, L., and Zarrellia, A. 2002b. A new dimeric 9,10dihydrophenanthrenoid from the rhizome of Juncus acutus, Tetrahedron Lett. 43: 2573-2575.

Doan, N. T., Rickards, R. W., Rothschild, J. M., and Smith, G. D. 2000 . Allelopathic actions of the alkaloid 12epi-hapalindole $\mathrm{E}$ isonitrile and calothrixin A from cyanobacteria of the genera Fischerella and Calothrix, J. Appl. Phycol. 12: 409-416.

Dodds, W. K. 1991. Community interactions between the filamentous alga Cladophora glomerata (L.) Kützing, its epiphytes, and epiphyte grazers, Oecologia 85: 572-580.

Duke, S. O., Dayan, F. E., Romagni, J. G., and Rimando, A. M. 2000. Natural products as sources of herbicides: current status and future trends, Weed Res. 40: 99111.

Duke, S. O., Scheffler, B. E., and Dayan, F. E. 2001. Allelochemicals as herbicides, in Physiological Aspects of Allelopathy, Reigosa, M. J., and Bonjoch, N. 
P., Eds., First European OECD Allelopathy Symposium, Vigo, Spain, pp. 47-59.

Dworjanyn, S. A., de Nys, N. R., and Steinberg, P. D. 1999. Localisation and surface quantification of secondary metabolites in the red alga Delisea pulchra, Mar. Biol. 133: 727-736.

Egan, S., Holmstrom, C., and Kjelleberg, S. $2001 \mathrm{a}$. Pseudoalteromonas ulvae sp. nov., a bacterium with antifouling activities isolated from the surface of a marine alga, Int. J. Syst. Evol. Micr. 51: 1499-1504.

Egan, S., James, S., Holmstrom, C., and Kjelleberg, S. 2001 b. Inhibition of algal spore germination by the marine bacterium Pseudoalteromonas tunicata, FEMS Microbiol. Ecol. 35: 67-73.

Einhellig, F. A. 1995. Mechanism of action of allelochemicals in allelopathy, ACS Sym. Ser. 582: 96-116.

Einhellig, F. A. 2001. The physiology of allelochemical action: clues and views, in Physiological Aspects of Allelopathy, Reigosa, M. J. and Bonjoch, N. P., Eds., First European OECD Allelopathy Symposium, Vigo, Spain, pp. 3-25.

Elakovich, S. D. and Wooten, J. W. 1989. Allelopathic potential of 16 aquatic and wetland plants, $J$. Aquat. Plant Manage. 27: 78-84.

Elakovich, S. D. and Wooten, J. W. 1991. Allelopathic potential of Nuphar lutea (L.) Sibth and Sm. (Nymphaeaceae), J. Chem. Ecol. 17: 707-714.

Elakovich, S. D. and Wooten, J. W. 1995. Allelopathic, herbaceous, vascular hydrophytes, ACS Sym. Ser. 582: 58-73.

Elakovich, S. D. and Yang, J. 1996. Structures and allelopathic effects of Nuphar alkaloids: Nupharolutine and 6,6'-dihydroxythiobinupharidine, J. Chem. Ecol. 22: 2209-2219.

El-Shatnawi, M. K. J. and Makhadmeh, I. M. 2001. Ecophysiology of the plant-rhizosphere system, J. Agron. Crop Sci. 187: 1-9.

Endean, R., Cameron, A. M., Fox, H. E., Tilbury, R., and Gunthorpe, L. 1997. Massive corals are regularly spaced: Pattern in a complex assemblage of corals, Mar. Ecol. Progr. Ser. 152: 119-130.

Ervin, G. N. and Wetzel, R. G. 2000. Allelochemical autotoxicity in the emergent wetland macrophyte Juncus effusus (Juncaceae), Am. J. Bot. 87: 853-860.

Farjalla, V. F., Anesio, A. M., Bertilsson, S., and Graneli, W. 2001. Photochemical reactivity of aquatic macrophyte leachates: abiotic transformations and bacterial response, Aquat. Microbial Ecol. 24: 187-195.

Fastner, J., Neumann, U., Wirsing, B., Weckesser, J., Wiedner, C., Nixdorf, B., and Chorus, I. 1999. Microcystins (hepatotoxic heptapeptides) in German fresh water bodies, Environ. Toxicol. 14: 13-22.

Fischer, 'N. H. and Quijano, L. 1985. Allelopathic agents from common weeds, ACS Sym. Ser. 268: 133-147.

Fischer, N. H., Williamson, G. B., Weidenhamer, J. D., and Richardson, D. R. 1994. In search of allelopathy in the Florida scrub - the role of terpenoids, J. Chem. Ecol. 20: 1355-1380.
Fish, S. A. and Codd, G. A. 1994a. Bioactive compound production by thermophilic and thermotolerant cyanobacteria (blue-green algae), World J. Microb. Biot. 10: 338-341.

Fish, S. A. and Codd, G. A. 1994b. Antimicrobial and cytotoxic activity produced by an isolate of the thermotolerant cyanobacterium (blue-green alga) Phormidium sp., Biotechnol. Tech. 8: 351-356.

Fitzgerald, G. P. 1969. Some factors in the competition or antagonism among bacteria, algae and aquatic weeds, J. Phycol. 5: 351-359.

Flessa, H. 1994. Plant-induced changes in the redox potential of the rhizospheres of the submerged vascular macrophytes Myriophyllum verticillatum L. and $R a$ nunculus circinatus L., Aquat. Bot. 47: 119-129.

Fleury, B. G., Coll, J. C., Tentori, E., Duquesne, S., and Figueiredo, L. 2000. Effect of nutrient enrichment on the complementary (secondary) metabolite composition of the soft coral Sarcophyton ehrenbergi (Cnidaria: Octocorallia: Alcyonaceae) of the Great Barrier Reef, Mar. Biol. 136: 63-68.

Flores, E. and Wolk, C. P. 1986. Production, by filamentous, nitrogen-fixing cyanobacteria, of a bacteriocin and of other antibiotics that kill related strains, Arch. Microbiol. 145: 215-219.

Forsberg, C., Kleiven, S., and Willen, T. 1990. Absence of allelopathic effects of Chara on phytoplankton in situ, Aquat. Bot. 38: 289-294.

Gallardo, M. T., Martin, B. B., and Martin, D. F. 1998a. An annotated bibliography of allelopathic properties of cattails, Typha spp., Florida Scient. 61: 52-58.

Gallardo, M. T., Martin, B. B., and Martin, D. F. 1998b. Inhibition of water fern Salvinia minima by cattail (Typha domingensis) extracts and by 2-chlorophenol and salicylaldehyde, J. Chem. Ecol. 24: 1483-1490.

Gallardo, M. T., Sawyers, W. G., and Martin, D. F. 1999. Concentrations of two phytotoxic materials in cattail extracts: 2-chlorophenol and salicylaldehyde, Florida Scient. 62: 164-171.

Gallardo-Williams, M. T., Geiger, C. L., Pidala, J. A., and Martin, D. F. 2002. Essential fatty acids and phenolic acids from extracts and leachates of southern cattail (Typha domingensis), Phytochemistry 59: 305-308.

Gleason, F. K. 1990. The natural herbicide, cyanobacterin, specifically disrupts thylakoid membrane structure in Euglena gracilis, Strain Z, FEMS Microbiol. Lett. 68: 77-81.

Gleason, F. K. and Baxa, C. A. 1986. Activity of the natural algicide, cyanobacterin, on eukaryotic microorganisms, FEMS Microbiol. Lett. 33: 85-88.

Gleason, F. K. and Case, D.E. 1986. Activity of the natural algicide cyanobacterin on angiosperms, Plant Physiol. 80: 834-838.

Gleason, F. K., Case, D. E., Sipprell, K. D., and Magnuson, T.S. 1986. Effect of the natural algicide cyanobacterin on a herbicide-resitant mutant of Anacystis nidulans R2, Plant Sci. 46: 5-10.

Gleason, F. K. and Paulson, J. L. 1984. Site of action of the natural algicide, cyanobacterin in the blue green alga, Synechococcus sp., Arch. Microbiol. 138: 273-277. 
Glomski, L. A. M., Wood, K. V., Nicholson, R. L., and Lembi, C. A. 2002. The search for exudates from Eurasian watermilfoil and Hydrilla, J. Aquat. Plant Manage. 40: 17-22.

Godmaire, H. and Planas, D. 1986. Influence of Myriophyllum spicatum on the species composition biomass and primary productivity of phytoplankton, Aquat. Bot. 23: 299-308.

Gopal, B. and Goel, U. 1993. Competition and allelopathy in aquatic plant communities, Bot. Rev. 59: 155-210.

Grace, J. B. 1983. Autotoxic inhibition of seed germination by Typha latifolia: an evaluation, Oecologia 59: 366369.

Grace, J. B. and Wetzel, R. G. 1978. The production biology of Eurasian watermilfoil (Myriophyllum spicatum L.): a review, J. Aquat. Plant Manage. 16: 1-11.

Griffith, J. K. 1997. Occurrence of aggressive mechanisms during interactions between soft corals (Octocorallia: Alcyoniidae) and other corals on the Great Barrier Reef, Australia, Mar. Freshwater Res. 48: 129-135.

Gromov, B. V., Vepritskiy, A. A., Titova, N. N., Mamkayeva, K. A., and Alexandrova, O. V. 1991. Production of the antibiotic cyanobacterin Lu-1 by Nostoc linckia Calu 892 (cyanobacterium), J. Appl. Phycol. 3: 5559.

Gross, E. M. 1999. Allelopathy in benthic and littoral areas: Case studies on allelochemicals from benthic cyanobacteria and submersed macrophytes, in Principles and Practices in Plant Ecology: Allelochemical Interactions, Inderjit, Dakshini, K. M. M., and Foy, C. L., Eds., CRC Press, Boca Raton, pp. 179-199.

Gross, E. M. 2000. Seasonal and spatial dynamics of allelochemicals in the submersed macrophyte Myriophyllum spicatum L., Verh. Internat. Verein. Limnol. 27: 2116-2119.

Gross, E. M., Meyer, H., and Schilling, G. 1996. Release and ecological impact of algicidal hydrolyzable polyphenols in Myriophyllum spicatum, Phytochemistry 41: 133-138.

Gross, E. M. and Sütfeld, R. 1994. Polyphenols with algicidal activity in the submerged macrophyte Myriophyllum spicatum L, Acta Horticul. 381: 710-716.

Gross, E. M., Wolk, C. P., and Jüttner, F. 1991. Fischerellin, a new allelochemical from the freshwater cyanobacterium Fischerella muscicola, J. Phycol. 27: 686-692.

Haeder, D. P., Kumar, H. D., Smith, R. C., and Worrest, R. C. 1998. Effects on aquatic ecosystems, J. Photoch. Photobiol. B 46: 53-68.

Hagmann, L. and Jüttner, F. 1996. Fischerellin A, a novel photosystem-II inhibiting allelochemical of the cyanobacterium Fischerella muscicola with antifungal and herbicidal activity, Tetrahedron Lett. 37: 6539-6542.

Harlin, M. M. 1987. Allelochemistry in marine macroalga, Crit. Rev. Plant Sci. 5: 237-249.

Harrison, P. G. and Chan, A. T. 1980. Inhibition of the growth of micro-algae and bacteria by extracts of eelgrass (Zostera marina) leaves, Mar. Biol. 61: 2126.
Harrison, P. G. and Durance, C. 1989. Seasonal variation in phenolic content of eelgrass shoots, Aquat. Bot. 35: 409-413.

Harrison, P. G. and Durance, C. D. 1985. Reduction in photosynthetic carbon uptake in epiphytic diatoms by water-soluble extracts of leaves of Zostera marina, Mar. Biol. 90: 117-120.

Haslam, E. 1989. Plant Polyphenols. Vegetable Tannins Revisited, Cambridge University Press, Cambridge.

Hasler, A. D. and Jones, E. 1949. Demonstration of the antagonistic action of large aquatic plants on algae and rotifers, Ecology 30: 359-364.

Hellio, C., Bremer, G., Pons, A. M., Le Gal, Y., and Bourgougnon, N. 2000. Inhibition of the development of microorganisms (bacteria and fungi) by extracts of marine algae from Brittany, France, Appl. Microbiol. Biot. 54: 543-549.

Hellio, C., Berge, J. P., Beaupoil, C., Le Gal, Y., and Bourgougnon, N. 2002. Screening of marine algal extracts for anti-settlement activities against microalgae and macroalgae, Biofouling 18: 205-215.

Hootsmans, M. J. M. and Blindow, I. 1994. Allelopathic limitation of algal growth by macrophytes, in Lake Veluwe, a Macrophyte-dominated System under Eutrophication Stress, van Vierssen, W., Hootsmans, M. J. M., and Vermaat , J. E., Eds., Kluwer Academic Publishers, Dordrecht, pp. 175-192.

Hough, R. A. and Filbin, G. J. 1990. Photosynthesis, photorespiration, and organic carbon release in Nymphaea tuberosa Paine and Nuphar variegatium Engelm, $J$. Freshwater Ecol. 5: 307-312.

Huppatz, J. L. 1996. Quantifying the inhibitor-target site interactions of photosystem II herbicides, Weed Science 44: 743-748.

Hutchinson, G. E. 1975. A Treatise on Limnology. Vol. III. Limnological Botany, John Wiley \& Sons, New York.

Ikawa, M., Haney, J. F., and Sasner, J. J. 1996. Inhibition of Chlorella growth by the lipids of cyanobacterium Microcystis aeruginosa, Hydrobiologia 331: 167-170.

Ikawa, M., Sasner, J. J., and Haney, J. F. 2001. Activity of cyanobacterial and algal odor compounds found in lake waters on green alga Chlorella pyrenoidosa growth, Hydrobiologia 443: 19-22.

Inderjit 1997. Is separating resource competition from allelopathy realistic? Bot. Rev. 63: 221-230.

Inderjit and Dakshini, K. M. M. 1994. Algal allelopathy, Bot. Rev. 60: 182-196.

Inderjit and Dakshini, K. M. M. 1995. On laboratory bioassays in allelopathy, Bot. Rev. 61: 28-44.

Inderjit and Dakshini, K. M. M. 1997. Allelopathic effect of cyanobacterial inoculum on soil characteristics and cereal growth, Can. J. Botany 75: 1267-1272.

Inderjit and Gross, E. M. 2002. Plant phenolics: potential role in aquatic and terrestrial ecosystems, in Polyphenols 2000, Martens, S., Forkmann, G., and D. Treutter, Eds. Proceedings of the XXth International Conference on Polyphenols, Freising-Weihenstefan (Germany), September 11-15, 2000, pp. 206-234. 
Inderjit. 2003. Crit Rev. Plant Sci. 22(3/4): 221-238.

Ishida, K. and Murakami, M. 2000. Kasumigamide, an antialgal peptide from the cyanobacterium Microcystis aeruginosa, J. Org. Chem. 65: 5898-5900.

Jackson, M. B. and Armstrong, W. 1999. Formation of aerenchyma and the processes of plant ventilation in relation to soil flooding and submergence, Plant Biology 1: 274-287.

Jasser, I. 1994. Influence of Ceratophyllum demersum on phytoplankton community in experimental conditions, Verh. Internat. Verein. Limnol. 25: 2291-2295.

Jasser, I. 1995. The influence of macrophytes on a phytoplankton community in experimental conditions, Hydrobiologia 306: 21-32.

Jenkins, K. M., Toske, S. G., Jensen, P. R., and Fenical, W. 1998. Solanapyrones E-G, antialgal metabolites produced by a marine fungus, Phytochemistry 49: 2299_ 2304.

Jennings, J. G. and Steinberg, P. D. 1994. In situ exudation of phlorotannins by the sublittoral kelp Ecklonia radiata, Mar. Biol. 121: 349-354,

Jennings, J. G. and Steinberg, P. D. 1997. Phlorotannins versus other factors affecting epiphyte abundance on the kelp Ecklonia radiata, Oecologia 109: 461-473.

Jeong, J., Jin, H., Sohn, C. H., Suh, K., and Hong, Y. 2000. Algicidal activity of the seaweed Corallina pilulifera against red tide microalgae, J. Appl. Phycol. 12: 37-43.

Jeppesen, E., Sondergaard, M., Sondergaard, M., and Christoffersen, K. 1998. The Structuring Role of Submerged Macrophytes in Lakes, Springer, New York.

Jüttner, F. 1999. Allelochemical control of natural photoautotrophic biofilms, in Biofilms in the Aquatic Environment, Keevil, C. W., Godfree, A., Holt, D., and Dow, C., Eds., Royal Society of Chemistry, Cambridge, pp. 43-50.

Jüttner, F. and Wu, J.-T. 2000. Evidence of allelochemical activity in subtropical cyanobacterial biofilms of Taiwan, Arch. Hydrobiol. 147: 505-517.

Jüttner, F., Todorova, A. K., Walch, N., and von Philipsborn, W. 2001. Nostocyclamide M: a cyanobacterial cyclic peptide with allelopathic activity from Nostoc 31, Phytochemistry 57: 613-619.

Kaebernick, M. and Neilan, B. A. 2001. Ecological and molecular investigations of cyanotoxin production, FEMS Microbiol. Ecol. 35: 1-9.

Kato-Noguchi, H. and Ino, T. 2001. Assessment of allelopathic potential of root exudate of rice seedlings, Biol. Plantarum 44: 635-638.

Kearns, K. D. and Hunter, M. D. 2000. Green algal extracellular products regulate antialgal toxin production in a cyanobacterium, Environ. Microbiol. 2: 291-297.

Kearns, K. D. and Hunter, M. D. 2001. Toxin-producing Anabaena flos-aquae induces settling of Chlamydomonas reinhardtii, a competing motile alga, Microbial Ecol. 42: 80-86.

Kearns, K. D. and Hunter, M. D. 2002. Algal extracellular products suppress Anabaena flos-aquae heterocyst spacing, Microbial Ecol. 43: 174-180.
Keating, K. I. 1977. Allelopathic influence on blue-green bloom sequence in a eutrophic lake, Science 196: 885-887.

Keating, K. I. 1978. Blue-green algal inhibition of diatom growth: transition from mesotrophic to eutrophic community structure, Science 199: 971-973.

Kjelleberg, S., Steinberg, P., Givskov, M., Gram, L., Manefield, M., and de Nys, R. 1997. Do marine natural products interfere with prokaryotic AHL regulatory systems? Aquat. Microb. Ecol. 13: 85-93.

Kogan, S. I. and Chinnova, G. A. 1972. Relations between Ceratophyllum demersum (L.) and some blue-green algae, Hydrobiol. J. (Ghidrobiol. Zh.) 8: 14-19 (2127).

Koh, E. G. L. and Sweatman, H. 2000. Chemical warfare among scleractinians: bioactive natural products from Tubastraea faulkneri Wells kill larvae of potential competitors, J. Exp. Mar. Biol. Ecol. 251: 141-160.

König, G. M., Wright, A. D., and Linden, A. 1999. Plocamium hamatum and its monoterpenes: chemical and biological investigations of the tropical marine red alga, Phytochemistry 52: 1047-1053.

Körner, S. and Nicklisch, A. 2002. Allelopathic growth inhibition of selected phytoplankton species by submerged macrophytes, J. Phycol. 38: 862-871.

Kreitlow, S., Mundt, S., and Lindequist, U. 1999. Cyanobacteria - a potential source of new biologically active substances, J. Biotechnol. 70: 61-63.

Kulshretha, M. and Gopal, B. 1983. Allelopathic influence of Hydrilla verticillata (L.F.) Royle on the distribution of Ceratophyllum species, Aquat. Bot. 16: 207-209.

Lam, C. W. Y. and Silvester, W. B. 1979. Growth interactions among blue-green (Anabaena oscillarioides, Microcystis aeruginosa) and green (Chlorella sp.) algae, Hydrobiologia 63: 135-143.

Lee, E.-S. J. and Gleason, F. K. 1994. A second algicidal natural product from the cyanobacterium Scytonema hofmanni, Plant Sci. 103: 155-160.

Lege, K. E., Cothren, J. T., and Smith, C. W. 1995. Phenolic acid and condensed tannin concentrations of six cotton genotypes, Environ. Exp. Bot. 35: 241-249.

Leu, E., Krieger-Liszkay, A., Goussias, C., and Gross, E. M. 2002. Polyphenolic allelochemicals from the aquatic angiosperm Myriophyllum spicatum L. inhibit photosystem II, Plant Physiol. 130: 2011-2018.

Lewis, R. J. and Holmes, M. J. 1993. Origin and transfer of toxins involved in ciguatera, Comp. Biochem. Phys. C 106: 615-628.

Lewis, W. M., Jr. 1986. Evolutionary interpretation of allelochemical interactions in phytoplanktonic algae, Am. Nat. 127: 184-194.

Littler, D. S. and Littler, M. M. 1997. Epizoic red alga allelopathic (?) to a Caribbean coral, Coral Reefs 16: 168.

Littler, M. M. and Littler, D. S. 1999. Blade abandonment/ proliferation: A novel mechanism for rapid epiphyte control in marine macrophytes, Ecology 80: 1736 . 1746. 
Lovett, J. V., Ryuntyu, M. Y., and Liu, D. L. 1989. Allelopathy, chemical communication, and plant defense, $J$. Chem. Ecol. 15: 1193-1202.

Madsen, J. D., Sutherland, J. W., and Bloomfield, L. W. 1991. The decline of native vegetation under dense Eurasian watermilfoil canopies, J. Aquat. Plant Manage. 29: 94-99.

Maestrini, S. Y. and Bonin, D. J. 1981. Allelopathic relationships between phytoplankton species, Can. B. Fish. Aquat. Sci. 210: 323-338.

Maida, M., Sammarco, P. W., and Coll, J. C. 1995a. Effects of soft corals on scleractinian coral recruitment. $I$. Directional allelopathy and inhibition of settlement, Mar. Ecol. Prog. Ser. 121: 191-202.

Maida, M., Sammarco, P. W., and Coll, J. C. 1995b. Preliminary evidence for directional allelopathic effects of the soft coral Sinularia flexibilis (Alcyonacea: Octocorallia) on scleractinian coral recruitment, $B$. Mar. Sci. 56: 303-311.

Martin, D. and Ridge, I. 1999. The relative sensitivity of algae to decomposing barley straw, J. Appl. Phycol. 11: 285-291.

Matsunaga, K., Kawaguchi, T., Suzuki, Y., and Nigi, G. 1999. The role of terrestrial humic substances on the shift of kelp community to crustose coralline algae community of the southern Hokkaido Island in the Japan Sea, J. Exp. Mar. Biol. Ecol. 241: 193-205.

Matsuyama, Y., Uchida, T., and Kotani, Y. 2000. Effect of culture filtrate of raphidophytes Heterosigma akshiwo and Chattonella antiqua on the growth of diatom Skeletonema costatum, Bull. Fish. Environ. Inland Sea 2: 57-66.

McClure, J. W. 1970. Secondary constituents of aquatic angiosperms, in Phytochemical Phylogeny, Harbome, J. B., Ed., Academic Press, London, pp. 234-268.

McCook, L. J., Jompa, J., and Diaz-Pulido, G. 2001. Competition between corals and algae on coral reefs: a review of evidence and mechanisms, Coral Reefs 19: $400-417$.

McLachlan, J. and Craigie, J. S. 1964. Algal inhibition by yellow ultraviolet-absorbing substances from Fucus vesiculosus, Can. J. Botany 42: 287-292.

McNaughton, S. J. 1968. Autotoxic feedback in relation to germination and seedling growth in Typha latifolia, Ecology 49: 367-369.

Mehra, A., Farago, M. E., Banerjee, D. K., and Cordes, K. B. 1999. The water hyacinth: an environmental friend or pest? A review, Res. Environ. Biotech. 2: 255-281.

Michalek-Wagner, K. and Bowden, B. F. 2000. Effects of bleaching on secondary metabolite chemistry of alcyonacean soft corals, J. Chem. Ecol. 26: 1543-1562.

Mjelde, M. and Faafeng, B. A. 1997. Ceratophyllum demersum hampers phytoplankton development in some small Norwegian lakes over a wide range of phosphorus concentrations and geographical latitude, Freshwater Biol. 37: 355-365.

Mohamed, Z. A. 2002. Allelopathic activity of Spirogyra $\mathrm{sp}$.: stimulating bloom formation and toxin produc- tion by Oscillatoria agardhii in some irrigation canals, Egypt, J. Plankton Res. 24: 137-141.

Molisch, H. 1937. Der Einfluss einer Pflanze auf die andere - Allelopathie, Fischer, Jena.

Moore, R. E. 1996. Cyclic peptides and depsipeptides from cyanobacteria: a review, J. Ind. Microbiol. 16: 134 143.

Mukhopadhyay, A., Chattopadhyay, J., and Tapaswi, P. K. 1998. A delay differential equations model of plankton allelopathy, Math. Biosci. 149: 167-189.

Nagle, D. G. and Paul, V. J. 1999. Production of secondary metabolites by filamentous tropical marine cyanobacteria: ecological functions of the compounds, J. Phycol. 35: 1412-1421.

Nakai, S., Hosomi, M., Okada, M., and Murakami, A. 1996. Control of algal growth by macrophytes and macrophyte-extracted bioactive compounds, Water Sci. Technol. 34: 227-235.

Nakai, S., Inoue, Y., Hosomi, M., and Murakami, A. 1999. Growth inhibition of blue-green algae by allelopathic effects of macrophyte, Water Sci. Technol. 39: 47-53.

Nakai, S., Inoue, Y., Hosomi, M., and Murakami, A. 2000. Myriophyllum spicatum-released allelopathic polyphenols inhibiting growth of blue-green algae Microcystis aeruginosa, Water Res. 34: 3026-3032.

Nalewajko, C. and Godmaire, H. 1993. Extracellular products of Myriophyllum spicatum L. as a function of growth phase and diel cycle, Arch. Hydrobiol. 127: 345-356.

Neori, A., Reddy, K. R., Ciskova-Koncalova, H., and Agami, M. 2000. Bioactive chemicals and biological-biochemical activities and their functions in rhizospheres of wetland plants, Bot. Rev. 66: 350-378.

Newman, J. R. and Barrett, P. R. F. 1993. Control of Microcystis aeruginosa by decomposing barley straw, J. Aquat. Plant Manage. 31: 203-206.

Nichols, D. S. and Keeney, D. R. 1976a. Nitrogen nutrition of Myriophyllum spicatum: uptake and translocation of ${ }^{15} \mathrm{~N}$ by shoots and roots, Freshwater Biol. 6: 145 154.

Nichols, D. S. and Keeney, D. R. 1976b. Nitrogen nutrition of Myriophyllum spicatum: variation of plant tissue nitrogen concentration with season and site in Lake Wingra, Freshwater Biol. 6: 137-144.

Nishizawa, M., Yamagishi, T., Nonaka, G. I., Nishioka, I., and Ragan, M. A. 1985. Tannins and related compounds, Part 34: Gallotannins of the freshwater green alga Spirogyra sp., Phytochemistry 24: 2411-2413.

Ohad, N. and Hirschberg, J. 1990. A similar structure of the herbicide binding-site in photosystem II of plants and cyanobacteria is demonstrated by site specific mutagenesis of the psba gene, Photosynth. Res. 23: 73-79.

Orth, R. J., Harwell, M. C., Bailey, E. M., Bartholomew, A., Jawad, J. T., Lombana, A. V., Moore, K. A., Rhode, J. M., and Woods, H. E. 2000. A review of issues in seagrass seed dormancy and germination: implications for conservation and restoration, Mar. Ecol. Progr. Ser. 200: 277-288. 
Ostensvik, O., Skulberg, O. M., Underdal, B., and Hormazabal, V. 1998. Antibacterial properties of extracts from selected planktonic freshwater cyanobacteria - a comparative study of bacterial bioassays, J. Appl.Microbiol. 84: 1117-1124.

Ostrofsky, M. L. and Zettler, E. R. 1986. Chemical defences in aquatic plants, $J$. Ecol. 74: 279-287.

Pandey, D. K. 1996. Phytotoxicity of sesquiterpene lactone parthenin on aquatic weeds, J. Chem. Ecol. 22: 151160.

Pandey, D. K., Kauraw, L. P., and Bhan, V. M. 1993a. Inhibitory effect of parthenium (Parthenium hysterophorus L.) residue on growth of water hyacinth (Eichhornia crassipes Mart Solms.) I. Effect of leaf residue, J. Chem. Ecol. 19: 2651-2662.

Pandey, D. K., Kauraw, L. P., and Bhan, V. M. 1993b. Inhibitory effect of parthenium (Parthenium hysterophorus L.) residue on growth of water hyacinth (Eichhornia crassipes Mart Solms.) II. Relative effect of flower, leaf, stem, and root residue, J. Chem. Ecol. 19: 2663-2670.

Pankow, H. 1961. Über die Ursachen des Fehlens von Epiphyten auf Zygnematalen, Arch. Protistenkd. 105: 417-444.

Papke, U., Gross, E. M., and Francke, W. 1997. Isolation, identification and determination of the absolute configuration of fischerellin B. A new algicide from the freshwater cyanobacterium Fischerella muscicola (Thuret.), Tetrahedron Lett. 38: 379-382.

Perez, E. 1999. Production of bioactive natural products by the green algae Nannochloris oculata and Nannochloris eucaryotum that inhibit Gymnodinium breve cultures, Dissertation Abstracts International Part B Science and Engineering, Sept 1999, vol. 1960, no. 1993, p. 1062.

Perez, E. and Martin, D. F. 2001. Critical micelle concentrations of allelopathic substances produced by Nannochloris oculata which affect a red tide organism, Gymnodinium breve, Cytobios 106: 163-170.

Peterson, C. G. and Tuchman, N. C. 1992. Substrata-associated microbiota, Water Environ. Res. 64: 625-632.

Pflugmacher, S. 2002. Possible allelopathic effects of cyanotoxins, with reference to microcystin-LR, in aquatic ecosystems, Environ. Toxicol. 17: 407-413.

Phillips, G. L., Eminson, D., and Moss, B. 1978. A mechanism to account for macrophyte decline in progressively eutrophicated freshwaters, Aquat. Bot. 4: 103-126.

Pickett-Heaps, J. D., Gunning, B. E., Brown, R. C., Lemmon, B. E., and Cleary, A. L. 1999. The cytoplast concept in dividing plant cells: Cytoplasmic domains and the evolution of spatially organized cell division, Am.J. Bot. 86: 153-172.

Pignatello, J. J., Porwoll, J., and Carlson, R. E. 1983. Structure of the antibiotic cyanobacterin, a chlorine-containing $\gamma$-lactone from the freshwater cyanobacterium Scytonema hofmanni, J. Org. Chem. 48: 4035-4038.

Pillinger, J. M., Cooper, J. A., and Ridge, I. 1994. Role of phenolic compounds in the antialgal activity of barley straw, J. Chem. Ecol. 20: 1557-1569.
Planas, D., Sarhan, F., Dube, L., and Godmaire, H. 1981. Ecological significance of phenolic compounds of Myriophyllum spicatum, Verh. Internat. Verein. Limnol. 21: 1492-1496.

Plumley, F. G. 1997. Marine algal toxins: biochemistry, genetics, and molecular biology, Limnol. Oceanogr. 42: $1252-1264$.

Porter, J. W. and Targett, N. M. 1988. Allelochemical interactions between sponges and corals, Biol. Bull. 175: 224-233.

Pushparaj, B., Pelosi, E., and Jüttner, F. 1998. Toxicological analysis of the marine cyanobacterium Nodularia harveyana, J. Appl. Phycol. 10: 527-530.

Quackenbush, R. C., Bunn, D., and Lingren, W. 1986. HPLC determination of phenolic acids in the water-soluble extracts of Zostera marina (eelgrass), Aquat. Bot. 24: 83-89.

Quayyum, H. A., Mallik, A. U., and Lee, P. F. 1999a. Allelopathic potential of aquatic plants associated with wild rice (Zizania palustris). I. Bioassay with plant and lake sediment samples, $J$. Chem. Ecol. 25: 209220.

Quayyum, H. A., Mallik, A. U., Orr, D. E., and Lee, P. F. 1999b. Allelopathic potential of aquatic plants associated with wild rice. II. Isolation and identification of allelochemicals, J. Chem. Ecol. 25: 221-228.

Ray, S. and Bagchi, S. N. 2001. Nutrients and $\mathrm{pH}$ regulate algicide accumulation in cultures of the cyanobacterium Oscillatoria laetevirens, New Phytol. 149: 455-460.

Reigosa, M. J., Sanchez-Moreiras, A., and Gonzalez, L. 1999. Ecophysiological approach in allelopathy, Crit. Rev. Plant Sci. 18: 577-608.

Rengefors, K. and Legrand, C. 2001. Toxicity in Peridinium aciculiferum - an adaptive strategy to outcompete other winter phytoplankton? Limnol. Oceanogr. 46: 1990-1997.

Rice, S. A., Givskov, M., Steinberg, P., and Kjelleberg, S. 1999. Bacterial signals and antagonists: The interaction between bacteria and higher organisms, $J$. Mol. Microb. Biotech. 1: 23-31.

Ridge, I., Walters, J., and Street, M. 1999. Algal growth control by terrestrial leaf litter: a realistic tool? Hydrobiologia 395/396: 173-180.

Rojo, C., Ortega-Mayagoitia, E., Rodrigo, M. A., and AlvarezCobelas, M. 2000. Phytoplankton structure and dynamics in a semiarid wetland, the National Park "Las Tablas de Daimiel”' (Spain), Arch. Hydrobiol. 148: 397-419.

Saito, K., Matsumoto, M., Sekine, T., and Murakoshi, I. 1989. Inhibitory substances from Myriophyllum brasiliense on growth of blue-green algae, J. Nat. Prod. 52: 1221-1226.

Sammarco, P. W. 1996. Comments on coral reef regeneration, bioerosion, biogeography, and chemical ecology: Future directions, J. Exp. Mar. Biol. Ecol. 200: 135-168.

Sand-Jensen, K. 1990. Epiphyte shading — its role in resulting depth distribution of submerged aquatic macrophytes, Folia Geobot. Phytotax. 25: 315-320. 
Sawitzky, H. and Grolig, F. 1995. Phragmoplast of the green alga Spirogyra is functionally distinct from the higher plant phragmoplast, J. Cell Biol. 130: 1359-1371.

Saxena, M. K. 2000. Aqueous leachate of Lantana camara kills water hyacinth, J. Chem. Ecol. 26: 2435-2447.

Scheffer, M. 1999. The effect of aquatic vegetation on turbidity; how important are the filter feeders? Hydrobiologia 409: 307-316.

Scheffer, M., Hosper, S. H., Meijer, M. L., Moss, B., and Jeppesen, E. 1993. Alternative equilibria in shallow lakes, Trends Ecol. Evol. 8: 275-279.

Schindler, D. W. 1977. Evolution of phosphorus limitation in lakes, Science 195: 260-262.

Schlegel, I., Doan, N. T., de Chazal, N., and Smith, G. D. 1998. Antibiotic activity of new cyanobacterial isolates from Australia and Asia against green algae and cyanobacteria, J. Appl. Phycol. 10: 471-479.

Shapiro, J. 1957. Chemical and biological studies on the yellow organic acids of lake water, Limnol. Oceanogr. 2: $161-179$.

Sieburth, J. M. 1968. The influence of algal antibiosis on the ecology of marine microorganisms, in Advances in Microbiology of the Sea, Droop, M.R. and Ferguson Wood, E. J., Eds., Academic Press, London, pp. 6394.

Singh, D. P., Tyagi, M. B., Kumar, A., Thakur, J. K., and Kumar, A. 2001. Antialgal activity of a hepatotoxinproducing cyanobacterium, Microcystis aeruginosa, World J. Microb. Biot. 17: 15-22.

Singh, H. P., Batish, D. R., and Kohli, R. K. 1999. Autotoxicity: concept, organisms, and ecological significance, Crit. Rev. Plant Sci. 18: 757-772.

Skulberg, O. M. 2000. Microalgae as a source of bioactive molecules: Experience from cyanophyte research, $J$. Appl. Phycol. 12: 341-348.

Slattery, M. and McClintock, J. B. 1997. An overview of the population biology and chemical ecology of three species of Antarctic soft corals, in Antarctic Communities: Species, Structure and Survival, Battaglia, B., Valencia, J., and Walton, D. W. H., Eds., Cambridge University Press, Cambridge, pp. 309-315.

Smayda, T. J. 1997. Harmful algal blooms: their ecophysiology and general relevance to phytoplankton blooms in the sea, Limnol. Oceanogr. 42: 1137-1153.

Smith, C. S. and Barko, J. W. 1990. Ecology of Eurasian watermilfoil, J. Aquat. Plant Manage. 28: 55-64.

Smith, G. D. and Doan, N. T. 1999. Cyanobacterial metabolites with bioactivity against photosynthesis in cyanobacteria, algae and higher plants, J. Appl. Phycol. 11: 337-344.

Smolders, A. J. P., Vergeer, L. H. T., van der Velde, G., and Roelofs, J. G. M. 2000. Phenolic contents of submerged, emergent and floating leaves of aquatic and semi-aquatic macrophyte species: why do they differ? Oikos 91: 307-310.

Søndergaard, M. 1981. Kinetics of extracellular release of ${ }^{14} \mathrm{C}$-labeled organic carbon by submersed macrophytes, Oikos 36: 331-347.
Sorrell, B. K. and Armstrong, W. 1994. On the difficulties of measuring oxygen release by root systems of wetland plants, J. Ecol. 82: 177-183.

Srivastava, A., Jüttner, F., and Strasser, R. J. 1998. Action of the allelochemical, fischerellin A on photosystem II, Biochim. Biophys. Acta 1364: 326-336.

Srivastava, V. C., Manderson, G. J., and Bhamidimarri, R. 1999. Inhibitory metabolites production by the cyanobacterium Fischerella muscicola, Microbial Res. 153: 309-317.

Steinberg, P. D., de Nys, R., and Kjelleberg, S. 2001. Chemical mediation of surface colonization, in Marine Chemical Ecology, McClintock, J. B. and Baker, B. J., Eds., CRC Press, Boca Raton, FL 355-387.

Sugg, L. M. and van Dolah, F. M. 1999. No evidence for an allelopathic role of okadaic acid among ciguateraassociated dinoflagellates, J. Phycol. 35: 93-103.

Sukenik, A., Eshkol, R., Livne, A., Hadas, O., Rom, M., Tchernov, D., Vardi, A., and Kaplan, A. 2002. Inhibition of growth and photosynthesis of the dinoflagellate Peridinium gatunense by Microcystis sp. (cyanobacteria): A novel allelopathic mechanism, Limnol. Oceanogr. 47: 1656-1663.

Sun, W.-H., Yu, S.-W., Yang, S.-Y., Zhao, P.-W., Yu, Z.W., Wu, H.-M., Huang, S.-Y., and Tang, C. S. 1993. Allelochemicals from root exudates of water hyacinth (Eichhornia crassipes) [Chinese], Acta Phytophysiol. Sin. 19: 92-96.

Sun, W. H., Yu, Z. W., Tai, G. F., and Yu, S. W. 1990. Sterilized culture of water hyacinth and its application in the study of allelopathic effect on algae [Chinese], Acta Phytophysiol. Sin. 16: 301-305.

Sütfeld, R. 1998. Polymerization of resorcinol by an cryptophycean exoenzyme, Phytochemistry 49: 451459.

Sütfeld, R., Petereit, F., and Nahrstedt, A. 1996. Resorcinol in exudates of Nuphar lutea, J. Chem. Ecol. 22: 22212231.

Suzuki, Y., Takabayashi, T., Kawaguchi, T., and Matsunaga, K. 1998. Isolation of an allelopathic substance from the crustose coralline algae, Lithophyllum spp., and its effect on the brown alga, Laminaria religiosa Miyabe (Phaeophyta), J. Exp. Mar. Biol. Ecol. 225: 69-77.

Sytsma, M. D. and Anderson, L. W. J. 1993. Nutrient limitation in Myriophyllum aquaticum, J. Freshwater Ecol. 8: $165-176$.

Szczepanska, W. 1987. Allelopathy in helophytes, Arch. Hydrobiol. Beih., Erg. Limnol. 27: 173-179.

Tang, C. S., Cai, W. F., Kohl, K., and Nishimoto, R. K. 1995. Plant stress and allelopathy, ACS Sym. Ser. 582: 142-157.

Tapaswi, P. K. and Mukhopadhyay, A. 1999. Effects of environmental fluctuation on plankton allelopathy, $J$. Math. Biol. 39: 39-58.

Thwaites, T. 2000. Killer from the sea, New Sci. 165: 7.

Todd, J. S., Zimmerman, R. C., Crews, P., and Alberte, R. S. 1993. The antifouling activity of natural and synthetic phenolic acid sulphate esters, Phytochemistry 34: 401404. 
Todorova, A. K. and Jüttner, F. 1995. Nostocyclamide - a new macrocyclic, thiazole-containing allelochemical from Nostoc sp. 31 (Cyanobacteria), J. Org. Chem. 60: 7891-7895.

Trebst, A., Donner, W., and Draber, W. 1984. Structure activity correlation of herbicides affecting plastoquinone reduction by photosystem. II: Electron density distribution in inhibitors and plastoquinone species, Zeitschr. Naturf. C 39: 405-411.

van den Berg, M. S., Coops, H., Meijer, M.-L., Scheffer, M., and Simons, J. 1998. Clear water associated with a dense Chara vegetation in the shallow and turbid Lake Veluwemeer, The Netherlands, in The Structuring Role of Submerged Macrophytes in Lakes, Jeppesen, E., Sondergaard, M., Sondergaard, M., and Christoffersen, K., Eds., Springer, New York, pp. 339 352.

Vance, H. D. and Francko, D. A. 1997. Allelopathic potential of Nelumbo lutea (Willd.) Pers. to alter growth of Myriophyllum spicatum L. and Potamogeton pectinatus L, J. Freshwater Ecol. 12: 405-409.

van Donk, E. and van de Bund, W. J. 2002. Impact of submerged macrophytes including charophytes on phyto- and zooplankton communities: allelopathy versus other mechanisms, Aquat. Bot. 72: 261-274.

Vardi, A., Schatz, D., Beeri, K., Motro, U., Sukenik, A., Levine, A., and Kaplan, A. 2002. Dinoflagellatecyanobacterium communication may determine the composition of phytoplankton assemblage in a mesotrophic lake, Curr. Biol. 12: 1767-1772.

von Elert, E. and Jüttner, F. 1996. Factors influencing the allelopathic activity of the planktonic cyanobacterium Trichormus doliolum, Phycologia 35: 68-73.

von Elert, E. and Jüttner, F. 1997. Phosphorus limitation and not light controls the extracellular release of allelopathic compounds by Trichormus doliolum (Cyanobacteria), Limnol. Oceanogr. 42: 1796-1802.

Vrba, J., Komarkova, J., and Vyhnalek, V. 1993. Enhanced activity of alkaline phosphatases phytoplankton response to epilimnetic phosphorus depletion, Water Sci. Technol. 28: 15-24.

Wahl, M. 1989. Marine epibiosis. I. Fouling and antifouling some basic aspects, Mar. Ecol. Progr. Ser. 58: 175190.

Weisner, S. E. B., Strand, J. A., and Sandsten, H. 1997. Mechanisms regulating abundance of submerged vegetation in shallow eutrophic lakes, Oecologia 109: 592-599.

Weithoff, G. and Walz, N. 1999. Problems in estimating phytoplankton nitrogen limitation in shallow eutrophic lakes, Hydrobiologia 408/409: 367-373.

Wetzel, R. G. 1969. Factors influencing photosynthesis and excretion of dissolved organic matter by aquatic mac- rophytes in hard-water lakes, Verh. Internat. Verein. Limnol. 17: 72-85.

Wetzel, R. G. 1991. Extracellular enzymatic interactions: Storage, redistribution, and interspecific communication, in Microbial Enzymes in Aquatic Environments, Chróst, R. J., Ed., Springer, New York, pp. 6-28.

Wetzel, R. G. 1993. Microcommunities and microgradients: Linking nutrient regeneration, microbial mutualism and high sustained aquatic primary production, Neth. J. Aquat. Ecol. 27: 3-9.

Wetzel, R. G. 2001. Limnology - Lake and River Ecosystems, $3^{\text {rd }}$ ed., Academic Press, San Diego.

Wetzel, R. G. and Manny, B. A. 1972. Secretion of dissolved organic carbon and nitrogen by aquatic macrophytes, Verh. Internat. Verein. Limnol. 18: 162-170.

Wiener, P. 2000. Antibiotic production in a spatially structured environment, Ecol. Lett. 3: 122-130.

Wigand, C., Stevenson, J. C., and Cornwell, J. C. 1997. Effects of different submersed macrophytes on sediment biogeochemistry, Aquat. Bot. 56: 233-244.

Williamson, C. E. 1995. What role does UV-B radiation play in freshwater ecosystems? Limnol. Oceanogr. 40: 386392.

Willis, R. J. 1985. The historical bases of the concept of allelopathy, J. Hist. Biol. 18: 71-102.

Winder, J. S., Cannell, R. J. P., Walker, J. M., Delbarre, S., Francisco, C., and Farmer, P. B. 1989. Glycosidase inhibitors from algae, Biochem. Soc. T. 17: 10301031.

Windust, A. J., Wright, J. L. C., and McLachlan, J. L. 1996. The effects of the diarrhetic shellfish poisoning toxins, okadaic acid and dinophysistoxin-1, on the growth of microalgae, Mar. Biol. 126: 19-25.

Wium-Andersen, S. 1987. Allelopathy among aquatic plants, Arch. Hydrobiol Beih., Erg. Limnol. 27: 167-172.

Wium-Andersen, S., Anthoni, U., and Christophersen, C. 1982. Allelopathic effects on phytoplankton by substances isolated from aquatic macrophytes (Charales), Oikos 39: 187-190.

Wium-Andersen, S., Anthoni, U., and Houen, G. 1983. Elemental sulphur, a possible allelopathic compound from Ceratophyllum demersum, Phytochemistry 22: 2613.

Wood, A. M., Rai, H., Gamier, J., Kairesalo, T., Gresens, S., Orive, E., and Ravail, B. 1992. Practical approaches to algal excretion, Mar. Microb. Food Webs 6: 21-38.

Wu, J. T., Kuo-Huang, L. L., and Lee, J. 1998. Algicidal effect of Peridinium bipes on Microcystis aeruginosa, Curr. Microbiol. 37: 257-261.

Young Cho, J., Kwon, E., Choi, J., Hong, S., Shin, H., and Hong, Y. 2001. Antifouling activity of seaweed extracts on the green alga Enteromorpha prolifera and the mussel Mytilus edulis, J. Appl. Phycol. 13: 117-125. 